\title{
Opera Scenes in Video Games: Hitmen, Divas and Wagner's Werewolves
}

\author{
TIM SUMMERS*
}

\begin{abstract}
This article aims to illuminate the meanings and aesthetic effects generated by scenes of staged opera in video games. It also explores the images of opera transmitted to the huge audiences that games address. Three dimensions of the opera-game encounter are discussed. First, Tosca in Hitman: Blood Money and The Beggar's Opera in Assassin's Creed III are used to examine the treatment of violence and the discourse of popular appeal in games and opera. Second, the arias sung by women in Final Fantasy VI and Parasite Eve illustrate how a melodramatic mode of expression represents a confluence of the aesthetic priorities of the two media. Finally, The Beast Within's meditation on Wagner reveals how opera sequences aim to engage players by conjuring phantasmagorias through a unifying and enrapturing spectacle.
\end{abstract}

I am fortunate enough to have made many trips to the opera. I have been 'at the opera' in concert halls, opera houses, amphitheatres and cinemas. I have witnessed opera through radio, CD, television and the internet. And I have even been to the opera in video games. In these visits, the action onstage and my own agency sometimes seem to blur together and conflate: I have assassinated in Tosca, committed crimes in The Beggar's Opera, and undergone transfiguration in a music drama by Wagner. These operas occur in a different mode of reality from my day-to-day life, but nevertheless serve as experiences that are part of my holistic musical and cultural existence.

In recent decades, rich traditions of filmic practice, opera staging and scholarly discourse have made us increasingly aware of the dialogues that exist between opera and film. ${ }^{1}$ Academic investigation has explored the multifaceted complexities of opera on screen, a domain that encompasses filmed recordings of staged opera, 'live' broadcasts, and representations of - and allusions to - opera in mainstream Hollywood film. What, then, of other sister moving-image media? Might equally revealing intersections exist in media such as video games?

* Tim Summers, University College Dublin, Ireland; timothy.summers@ucd.ie The author is grateful to Jennifer Sheppard, Peter Tregear and the anonymous readers for their perceptive comments and advice on earlier drafts of this article.

1 Notable recent scholarship in this area includes the work of Michal Grover-Friedlander, Vocal Apparitions: The Attraction of Cinema to Opera (Princeton, 2005); Jeongwon Joe, Opera as Soundtracke (Farnham, 2013) and, edited with Sander L. Gilman, Wagner and Cinema (Bloomington, 2010); and Marcia J. Citron, When Opera Meets Film (Cambridge, 2010), 'The Operatics of Detachment: Tosca in the James Bond Film Quantum of Solace', 19th-Century Music 34 (2011), 316-40, and 'Opera and Film', in The Oxford Handbook of Film Music Studies, ed. David Neumeyer (New York, 2014), 44-71. 
Video games have a long history of using musical excerpts from opera. ${ }^{2}$ Such music, however, is not often presented in terms of staged opera. Opera in games is more commonly sounded either as part of general playlists of 'classical' art music, ${ }^{3}$ or as intertextual references to quotations of opera in other media. ${ }^{4}$ Even the video games based on Der Ring des Nibelungen do not depict a staged operatic work in any traditional way. ${ }^{5}$ These instances might be best considered as part of the broader practice of the citation of art music in games. ${ }^{6}$ This present investigation, however, is instead concerned specifically with moments of staged opera in games.

The aim is to explore situations where opera is directly depicted as occurring in the fictional narrative world of the games; what Marcia J. Citron would describe as 'opera visits'. The tradition of the 'opera visit' has become an established conceit for films and other popular narrative media. In games, such examples include the staging of pre-existing operas, as well as scenes that present new compositions.

I offer two justifications for this scholarly inquiry. First, these moments where games and opera intersect have the potential to provide insight into the constitutional media. To borrow Michal Grover-Friedlander's comments (originally made regarding film and opera), the interactions of video games with opera might 'teach us something about the exchange between the two media, and ... the transformation of one medium into the other may reveal unanticipated or previously unarticulated characteristics of each, ${ }^{8}$

Second, beyond this opportunity for informative intermedial dialogue, there is a distinctly pragmatic necessity for this investigation. While it would be erroneous to

2 Citations of opera in games can be traced at least as far back as Route-16 (1981), which used the chorus melody of the 'Toreador aria' from Carmen.

3 Gamers may hear opera recordings on the simulated 'classical music' radio stations of racing games, such as Test Drive Unlimited (2006), Burnout Paradise (2008), Forza Horizon 2 (2012) and The Crew (2014). As William Gibbons has described, when selections of classical music are remixed in Boom Boom Rocket (2007), music from opera is among the excerpts so adapted. William Gibbons, 'Remixed Metaphors: Manipulating Classical Music and its Meanings in Video Games', in Ludomusicology, ed. Michiel Kamp, Tim Summers and Mark Sweeney (Sheffield, 2016), 198-222, esp. 206-10.

4 Games that pay homage to (or parody) famous uses of opera in films/television may replicate the music as part of the citation: the Guillaume Tell overture is predictably heard in The Lone Ranger game (1991), while some scenes of spectacular violence in Batman: Arkham Origins (2013) share the overture to La gazza ladra with A Clockwork. Orange (1971). In the battle game Return Fire (1995), the 'Ride of the Valkyries' sounds when the player controls helicopters, clearly referring to Apocalypse Now (1979). On The Lone Ranger, see Jonathan Godsall, 'Hi-yo, Rossini: The Lone Ranger's Impact on William Tell, paper presented at the Music for Audio-Visual Media Conference II, Leeds, UK, 21 June 2016.

5 Tim Summers, 'From Parsifal to the PlayStation: Wagner and Video Game Music', in Music in Video Games, ed. K.J. Donnelly, William Gibbons and Neil Lerner (New York, 2014), 199-216.

6 William Gibbons, 'Blip, Bloop, Bach? Some Uses of Classical Music on the Nintendo Entertainment System', Music and the Moving Image 2 (2009), 40-52. We eagerly await William Gibbons's monograph, which will serve as a comprehensive treatment of this subject: Unlimited Replays: Classical Music and the Meanings of Art in Video Games (New York, forthcoming).

7 Citron, 'The Operatics of Detachment', 316.

8 Grover-Friedlander, Vocal Apparitions, 2. 
characterise video games as the exclusive domain of the young, ${ }^{9}$ video games retain a distinct youth appeal and capture a substantial proportion of young people in modern Western society (one oft-cited statistic estimates that $91 \%$ of American children play games). ${ }^{10}$ When games have such great cultural permeation and present opera to those still forming notions of adult culture, opera in games potentially serves an educational function. It is therefore important to consider how opera is being presented in this context and which images and conceptions of the medium are being created, reinforced or disavowed.

Methodologically, this article follows in the footsteps of the hermeneutic tradition of scholarship established both within game music and studies of opera on screen. The writings of William Cheng and William Gibbons on musical experiences in games represent significant precedents for the approach adopted here. ${ }^{11}$ It is important to respect the differences between films and games (a topic to which I shall return), but with this awareness in mind, research on opera scenes in film provides a useful starting foundation for this investigation. I draw here on studies by Citron, Jeongwon Joe and Marc A. Weiner, amongst others. $^{12}$

In line with Joe, 'my analyses are not drawn from the [creators'] intentionality but [from] my reading of the interplay of sonic and visual signifiers'. ${ }^{13}$ Part of the position I adopt is based on my own experience as a player, in the model of Cheng's 'hands-on experiences with gameworlds' and 'critical interpretations'. 14 After Nicholas Cook and the game theorist James Paul Gee, I consider gamers as actively investigative media consumers, 'reading' the game and creating musical meanings as they encounter the multimedia text. ${ }^{15} \mathrm{~A}$ hermeneutic approach is especially apt for video games. Players are encouraged to undertake such interpretation even more than in film, because of the interactive dimension of the medium which demands players respond to the game. As Karen Collins writes, 'the stakes for players' involvement, interpretation and therefore attention are much

9 Entertainment Software Association, 2016 Sales, Demographic and Usage Data: Essential Facts About the Computer and Video Game Industry (Washington DC, 2016), www.theesa.com/wp-content/uploads/ 2016/04/Essential-Facts-2016.pdf.

10 David Riley, 'The Video Game Industry is Adding 2-17 Year-Old Gamers at a Rate Higher than that Age Group's Population Growth', NPD Group (11 October 2011), web.archive.org/web/ 20120415174158/http://www.npdgroup.com/wps/portal/npd/us/news/pressreleases/ pr_111011.

11 William Cheng, Sound Play: Video Games and the Musical Imagination (New York, 2013); William Gibbons, 'Wrap Your Troubles in Dreams: Popular Music, Narrative, and Dystopia in Bioshock', Games Studies 11 (2011).

12 Citron, When Opera Meets Film; Joe, Opera as Soundtrack; Marc A. Weiner, 'Why Does Hollywood Like Opera?', in Between Opera and Cinema, ed. Jeongwon Joe and Rose Theresa (New York, 2002), 75-91.

13 Joe, Opera as Soundtrack, 24.

14 Cheng, Sound Play, 14.

15 Nicholas Cook, Analysing Musical Multimedia (Oxford, 1998); James Paul Gee, What Video Games Have to Teach Us About Learning and Literacy (New York, 2003), 23. 
higher in games [than film], so they listen more actively'. ${ }^{16}$ An attitude of interpretation is prompted by the media parameters and embedded in the players' engagement with the medium.

It is my intention here to interrogate the aesthetic discourse of these opera scenes. I attempt to understand how the operatic materials and the cultural meanings of opera are drawn upon and reconfigured through their sounding in games. As part of this exploration, antecedent critical histories of opera are placed in dialogue with the manifestations of opera in games. This way, we might appreciate how games represent and deploy operatic experiences for the players. In short, these opera scenes are 'read' in their game context for their meanings and aesthetic effects, in order to uncover what these games 'say' about opera, and what opera 'does' in games.

This article explores five games chosen for both their treatment of opera and their dissemination. All the games feature staged opera as part of a sequence that clearly aims to form a significant part of the aesthetic experience of the game. The games are highprofile mainstream titles that collectively have sold near twenty million copies. ${ }^{17}$ While the group has a diversity of musical material, game type, historical range and computer technology, they nevertheless usefully inform one another in a critical manner.

\section{Hitmen}

Following the precedent of films such as The Godfather Part III (1990), Quantum of Solace (2011) and Mission: Impossible - Rogue Nation (2015), some games depict scenes of assassination and violence simultaneously with staged opera. ${ }^{18}$ As Jeongwon Joe writes:

[the] use of operatic music in conjunction with cinematic death, especially ritualized, stylized, and climactic murder scenes, has been notable across diverse genres of popular titles ... [serving] as a sonic enhancement of [filmic] death scenes. ${ }^{19}$

Citron discusses how Tosca acts as a backdrop for a violent confrontation in the James Bond film Quantum of Solace. She observes that this filmic presentation of

16 Karen Collins, Playing With Sound: A Theory of Interacting with Sound and Music in Video Games (Cambridge, MA, 2013), 22.

17 Assassin's Creed III (12 million copies by February 2013), Final Fantasy VI (3.48 million copies by March 2003), Hitman: Blood Money (2.1 million copies by May 2011), Parasite Eve (1.94 million copies by March 2003). No reliable sales data was available for Gabriel Knight 2: The Beast Within, but the recent re-release of the game on the Steam platform showed 62,000 downloads. John Gaudiosi, 'New "Hitman: Absolution" Game Uses "Avatar" Performance Capture Technology, Hollywood Talent', The Hollywood Reporter (11 May 2011), web.archive.org/web/20120101230615/http:// www.hollywoodreporter.com/news/new-hitman-absolution-game-uses-187550; Tom Ivan, 'Assassin's Creed 3: 12 million sales boost Ubisoft's Q3', Computer and Video Games (7 February 2013), web.archive.org/web/20130702093554/http://www.computerandvideogames. com:80/389939/assassins-creed-3-12-million-sales-boost-ubisofts-q3; Square Enix Co. Ltd, Square Enix (Business Report) (February 2004), web.archive.org/web/20131109063558/http://www.jp. square-enix.com/ir/e/explanatory/download/0404-200402090000-01.pdf; Steamspy, 'Activision', Steamspy.com (2017), steamspy.com/dev/Activision.

18 Citron, When Opera Meets Film, 43-57; and Lars Franke, 'The Godfather Part III: Film, Opera, and the Generation of Meaning', in Changing Tunes: The Use of Pre-Existing Music in Film, ed. Phil Powrie and Robynn Stilwell (Farnham, 2006), 31-45.

19 Joe, Opera as Soundtrack, 56-7. 
opera departs from the typical opera visit, where 'opera appears in an idealized light. It stands for high art, possesses transformative powers, and serves as an uplifting experience that embodies the best of Western culture. ${ }^{20}$ In Quantum of Solace, however, Citron argues that the opera is presented without idealisation, as an 'isolating phenomenon', with a 'detached operatic subjectivity'. ${ }^{21}$

Two games, Hitman: Blood Money (2006) and Assassin's Creed III (2012), both ask the player to enact an assassination during the performance of a staged opera. Predating the Quantum of Solace film by some five years, Hitman: Blood Money used the same opera, Tosca, as the setting for opera house violence. The Hitman games belong to the 'stealth' game genre, where the player must achieve game objectives by directing an avatar through a virtual environment while avoiding detection by the enemies. Typical challenges include infiltration, theft or, as in the case of Hitman, assassination.

In the Tosca level, the gamer, playing the role of hitman Agent 47, must arrange the assassination of two targets during rehearsals at the Palais Garnier in Paris: a tenor playing the role of Cavaradossi (Alvaro d'Alvade) and a diplomat watching the rehearsals. As Cheng writes:

[A]s d'Alvade and his fellow NPCs [non-playable characters] run the final scene again and again, the player receives multiple chances to observe their actions and to hatch an ideal plan. ... That d'Alvade and his castmates are rehearsing only the final scene of Tosca also means that ... the perfect window of opportunity - Cavaradossi's execution - comes up. ${ }^{22}$

There are several ways that the player can choose to eliminate the tenor. One might replace a prop gun with a real one, use the staged shot to cover the sound of Agent 47's own lethal bullet, or have Agent 47 play the role of the soldier who executes Cavaradossi, assassinating d'Alvade on stage (see Fig. 1 and Ex. 1). Concerning the other target - the diplomat - the favoured mode of murder is crushing him with a chandelier, in a moment reminiscent of The Phantom of the Opera, set in this same theatre. $^{23}$

In his evocative discussion of the level, Cheng notes how this sequence toys with its nested fictions, especially the confusion between real death and acted death that happens on both the level of the story of Tosca (where Tosca initially believes Cavaradossi is only playing dead) and the diegetic action of Hitman (where the other actors initially believe d'Alvade is only playing dead). ${ }^{24}$ Since his concerns lie elsewhere, Cheng does not consider the sequence's significance as a specifically operatic moment. Tosca is, nonetheless, integral to the aesthetic experience of the level and the discourse about the opera that the game articulates.

20 Citron, 'The Operatics of Detachment', 317

21 Citron, 'The Operatics of Detachment', 318.

22 Cheng, Sound Play, 169-70.

23 The Phantom of the Opera also places opera and violence in dialogue. On these themes in the 1927 film, see Michal Grover-Friedlander, "The Phantom of the Opera": The Lost Voice of Opera in Silent Film', Cambridge Opera Journal 11 (1999), 179-92.

24 Cheng, Sound Play, 171. 


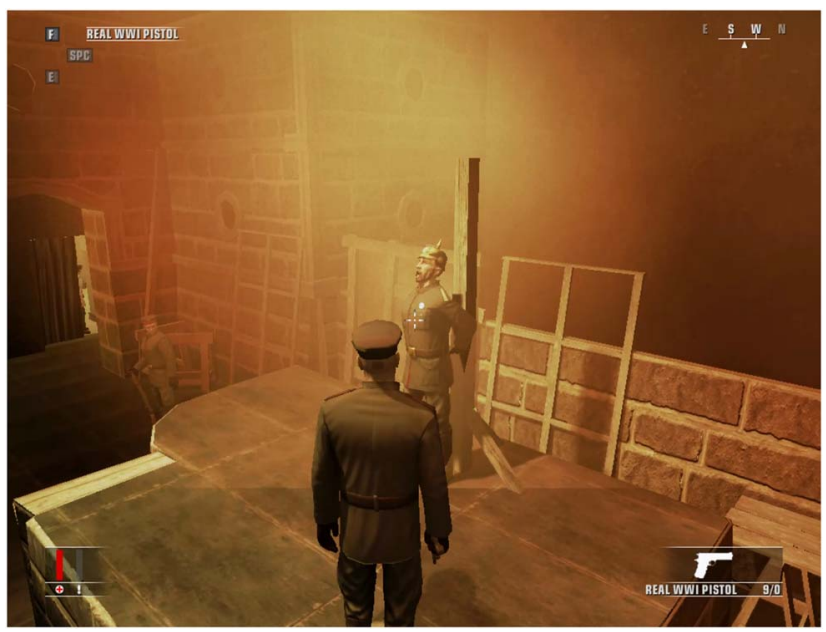

Fig. 1: In Hitman: Blood Money, tenor Alvaro d'Alvade sings as Cavaradossi while Agent 47, disguised as a soldier, waits for the appropriate moment to assassinate him. Screen capture by Tim Summers, 10 September 2017.

It is useful to interrogate this Hitman level alongside another game featuring murder at the opera. Assassin's Creed III is a game with a play mechanic that is often similar to Hitman, involving covert action and homicide. The Assassin's Creed games take place primarily in historical settings. At the start of the third game, the player adopts the role of Haytham Kenway, a nobleman attending a performance at the Theatre Royal, Covent Garden in 1754. The performance is one of John Gay's The Beggar's Opera and is described by the game's characters as a revival. The Beggar's Opera was performed five times in Covent Garden during $1754,{ }^{25}$ but given the regularity of the performances of the work in the preceding years (at both Covent Garden and elsewhere), the notion of a 'revival' is rather historically misleading.

While Kenway enters the auditorium, the opera house's period-instrument orchestra is heard playing Johann Christoph Pepusch's 'Ouverture'. ${ }^{26}$ When the player directs Kenway to sit down, the music skips to the final chords of the overture, before the first ballad, 'Through All the Employments of Life', starts to be performed by the actor playing Peachum (Fig. 2). ${ }^{27}$ Kenway's target is a member of the audience, sitting

25 In 1754 The Beggar's Opera was performed at Covent Garden on 21 March, 18 May, 16 September, 11 November and 30 November, and a further six times at Drury Lane during the same calendar year. George Winchester Stone, Jr, ed., The London Stage 1660-1800: Part IV, 1747-1776, Vol. 1 (Carbondale, 1962), 408-59.

26 The speech preceding the overture has been omitted in the game. John Gay, The Beggar's Opera \& Polly, Reprinted from the First Editions (1728-9) with the Airs of the Music (London, 1923), 16-24.

27 A member of the company waiting in the wings can be overheard referring to one of the actors on the stage during the scene between Peachum and Filch as 'Jeremy'. None of the recorded actors playing Peachum or Filch in the 1754 productions at Covent Garden or Drury Lane had the name 'Jeremy', indicating that it is at this level of specificity that our world history and the fictional world of the game diverge. 


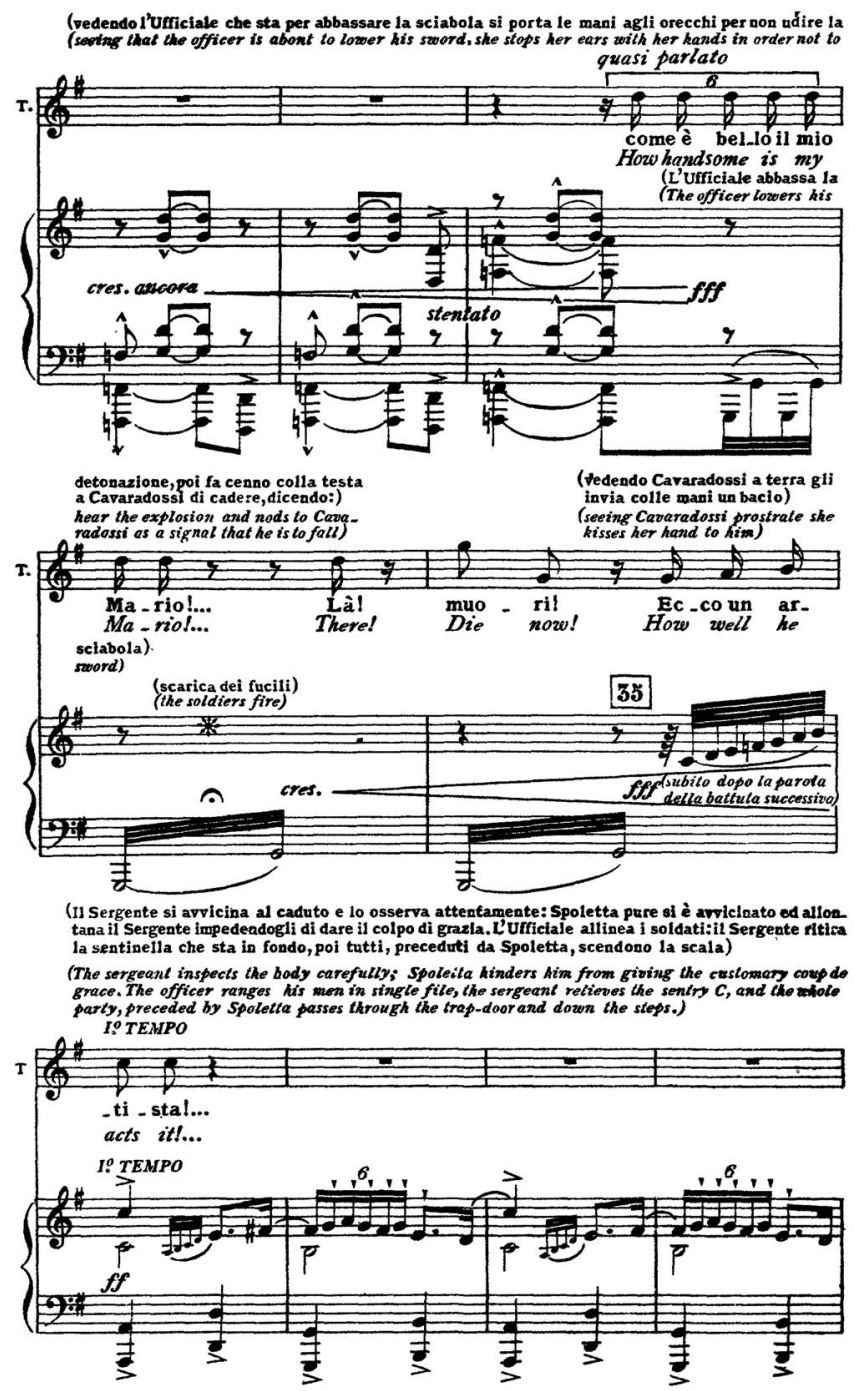

Ex. 1: Cavaradossi is killed in the third act of Tosca. The moment in the score marked with * is also when the assassination of tenor d'Alvade occurs in Hitman: Blood Money.

in one of the boxes. Kenway must make his way from his stalls seat on stage right, to the box, stage left, by sneaking across the top of the stage, using the gangways and clinging to the suspended scenery, while the opera is being performed below him. The songs and dialogue of The Beggar's Opera continue to play out during this part of the game. When Kenway reaches the box, the operatic action cuts to Mrs Peachum's air, 'If Any Wench Venus's Girdle Wear' (see Ex. 2). This aria accompanies the sequence in which the target realises he is about to be killed, converses with Kenway, and is ultimately executed when the player presses a button to have Kenway do the deed. Kenway steals jewellery from his victim and leaves the box to make his escape. While 


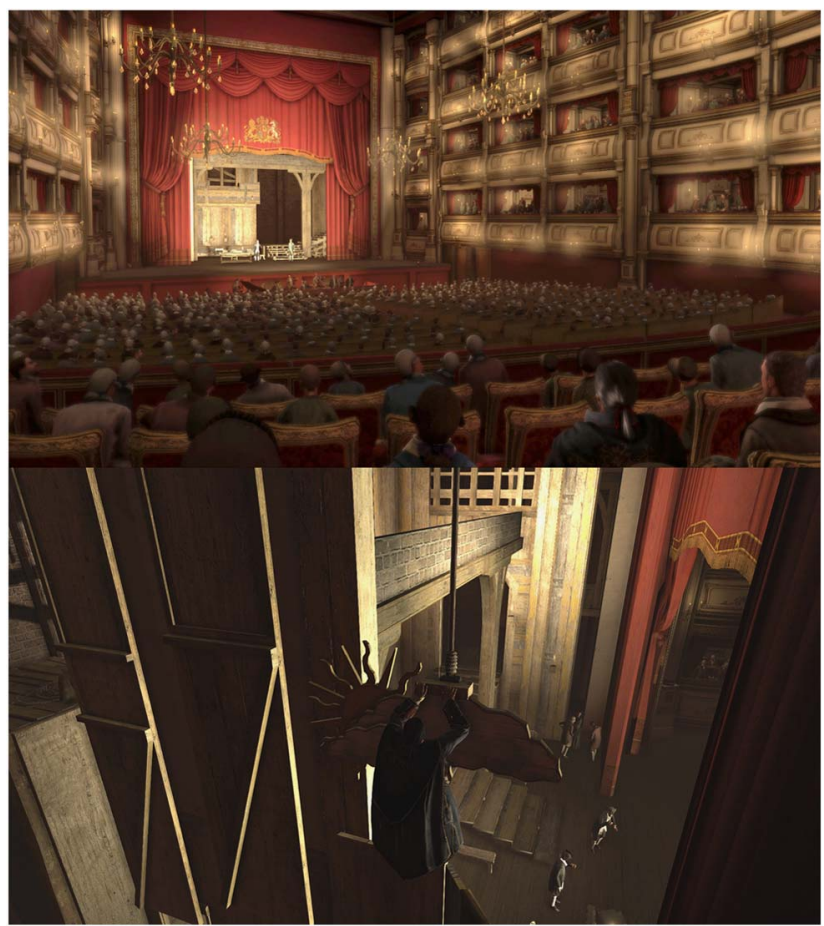

Fig. 2: Haytham Kenway attends Covent Garden in Assassin's Creed III. He reaches his victim by crossing the stage while the opera is performed. Screen capture by Tim Summers, 20 February 2018.

Mrs Peachum continues to sing on stage, it is not long before the opera halts, upon the discovery of the death.

Though The Beggar's Opera is of a distinctly different genre to the kinds of opera usually used in opera visits in film (Italian opera tends to dominate), this piece is nevertheless apt for Assassin's Creed. The geographic/historic setting of the game provides certain boundaries for the operatic repertoire that could be included, and, in doing so, the presentation of this opera serves to help define those same contextual factors for the player. More than simple couleur locale/couleur historique, however, the piece is thematically felicitous for Assassin's Creed, much as Tosca is for Hitman.

Both Tosca and The Beggar's Opera have long provoked controversy among audiences and critics. Tosca's spectacle, violence, excesses of emotional expression and dramatic contrivances has led to a history of its reception as a sensationalist work of 'shameless theatricality' written to appeal to a wide audience. ${ }^{28}$ As Peter Franklin describes:

[Tosca's] sure-fire success with audiences has also, since its first night, been matched by the disapproval of idealistic critics. Validating its classification by finding its violence

28 Richard Specht, Giacomo Puccini-The Man, His Life, His Work, trans. Catherine A. Phillips (London, 1933), ix, quoted in Peter Franklin, 'Movies as Opera (Behind the Great Divide)', in A Night in at the Opera: Media Representations of Opera, ed. Jeremy Tambling (London, 1994), 88. 
A I R III. Cold and Raw, Eंc.

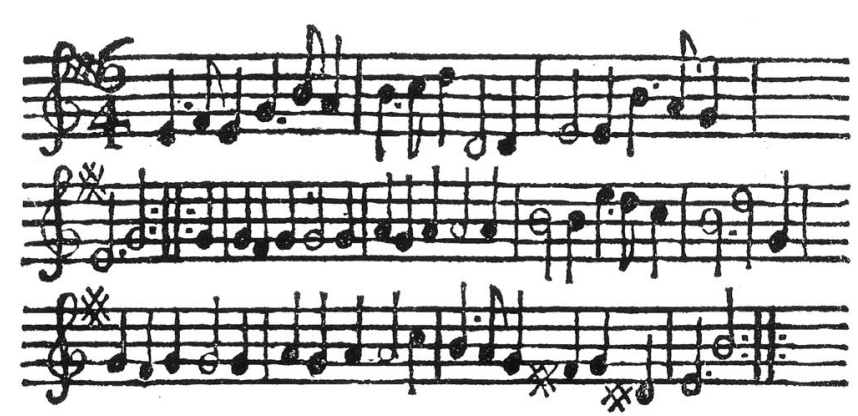

If any Wench Venus's Girdle wear, Though she be never so ugly;

Lillies and Roses will quickly appear, And her Face look wond'rous smuggly.

Beneath the left Ear so fit but a Cord, (A Rope so charming a Zone is!)

The Youth in his Cart hath the Air of a Lord, And we cry, There dies an Adonis!

Ex. 2: Mrs Peachum's Air, 'If Any Wench Venus's Girdle Wear' from The Beggar's Opera.

'repellent', they have always located it firmly, and damningly, within the arena of popular culture. ${ }^{29}$

In the year of Tosca's premiere, Michele Virgillio wrote that 'Tosca and Scarpia are people created by a sick imagination in a moment of aesthetic aberration. ${ }^{30}$ Such criticism of Puccini with reference to illness continued. Fausto Torrefranca's well-known attack on Puccini in terms of sickness and decadence was published in 1912, ${ }^{31}$ and in 1920, Adolf Weissmann wrote:

Puccini is the master of the art of persuasion. In the hotels and cafés, he whispers in the Kapellmeister's ear: With my notes you will conquer. In New York, London, Berlin, Paris - the same spectacle of seduction by Puccini's cantilenas ... 'Puccinismus' has become a sickness. ${ }^{32}$

Tosca's violence caused contemporary commentators, in Alexandra Wilson's summary, 'concern for the nation's moral well-being. 33 Similarly, The Beggar's Opera was attacked for its 'alleged unethical influence', with critics claiming that 'such an

29 Franklin, 'Movies as Opera', 83.

30 Quoted in Alexandra Wilson, The Puccini Problem Opera, Nationalism, and Modernity (Cambridge, 2007), 76.

31 On Torrefranca's criticism, see Wilson, The Puccini Problem, 125-54.

32 Adolf Weissmann, Der Klingende Garten (Berlin, 1920), 55-6, quoted in Franklin, 'Movies as Opera', 88.

33 Wilson, The Pucini Problem, 74. 
Entertainment must highly tend to corrupt and debauch the Morals of the Nation'.34 The work was also blamed for inspiring real-world violent criminal activity. In 1776, music historian John Hawkins painted an extensive picture of criminality prompted by the work, writing that:

The effects of The Beggar's Opera on the minds of the people, have fulfilled the prognostications of many that it would prove injurious to society. Rapine and violence have been gradually increasing ever since its first representation. ${ }^{35}$

Such discussion of fictional artworks in terms of moral influence anticipates the similar, much later, criticism of video games as dangerous and corrupting popular entertainment. In the words of Christopher J. Ferguson and John Kilburn, 'Over the last two decades, society has expressed concern that violent video games ... may play some role in youth violence. ${ }^{36}$ In particular, a moral panic about games developed in the aftermath of school shootings in the United States during the 1990 s. $^{37}$ The discussion in popular media was almost entirely divorced from any scholarly research into the connections between games and violence. Instead, as sociologist Karen Sternheimer notes, documenting the history of this alarmist thought:

Video games, those who play them, and those who create them have become contemporary folk devils [individuals or groups defined as evil and immoral] because they seem to pose a threat to children. ${ }^{38}$

The US Senate hearings on children and violence that took place at the turn of the millennium are emblematic of the hysteria that blamed video games for tragic acts of violence. In these sessions, video games were repeatedly characterised as 'force-fed to vulnerable and impressionable children ... placing their hearts, their minds, and yes, their souls at risk', and as a 'toxic substance ... pouring into our children's

34 A 1728 letter to The London Journal, quoted in William Eben Schultz, Gay's Beggar's Opera (New Haven, 1923), 232.

35 Quoted in Schultz, Gay's Beggar's Opera, 254. For an extensive treatment of the reception of the work in terms of morality, see Schultz, Gay's Beggar's Opera, 226-69.

36 Christopher J. Ferguson and John Kilburn, 'Much Ado About Nothing: The Misestimation and Overinterpretation of Violent Video Game Effects in Eastern and Western Nations', Psychological Bulletin 136 (2010), 174.

37 Notorious lawyer Jack Thompson claimed that the Columbine massacre 'was the result of a teen filled up with violent entertainment and trained on violent entertainment, video games, to kill'. Quoted in David Kushner, Jacked (London, 2012), 62. Thompson has continued to blame games for similar incidents since Columbine.

38 Karen Sternheimer, 'Do Video Games Kill?', Contexts 6 (2007), 13. For further explorations of media reports of tragedies that blame video games for real-world violence, see Nicholas D. Bowman, 'The Rise (and Refinement) of Moral Panic', in The Video Game Debate, ed. Rachel Kowert and Thorsten Quandt (New York, 2016), 22-38; Allen Copenhaver, 'Violent Video Game Legislation as Pseudo-Agenda', Criminal Justice Studies 28 (2015), 170-85; Richard Dillio, 'A Critical Miss: Video Games, Violence, and Ineffective Legislation', First Amendment Studies 48 (2014), 110-30; and Christopher J. Ferguson, 'The School Shooting/Violent Video Game Link: Causal Link or Moral Panic?', Journal of Investigative Psychology and Offender Profiling 5 (2008), 25-37.

39 Senator Henry Hyde, quoted in Marketing Violence to Children: Hearing Before the Committee on Commerce, Science, and Transportation, United States Senate One Hundred Sixth Congress, Second Session (13 September 2000), 27. 
lives, 40 responsible for the murderous acts of children alongside violent films and rock music. ${ }^{41}$ Graphic video games, The Beggar's Opera and Tosca, due to their alluring treatment of violence and criminality, have all been deigned 'shabby little shocker[s]', to use a famous description of Puccini's opera. ${ }^{42}$

In their combination of death and staged opera, meanwhile, it may be tempting to read Hitman and Assassin's Creed simply as a continuation of the filmic tradition identified by Joe and Citron; part of a video game aesthetic that looks to its more prestigious silver-screen sibling and seeks to emulate its style. While the drive for cinematic audio aesthetics in games has been well documented, ${ }^{43}$ it is important to recognise that the nature of the video game medium adds complicating factors to these opera visits.

Joe sees the film trope of death and opera as a manifestation of opera's preoccupation with death that extends across national practices, chronological eras and operatic genres. ${ }^{44}$ Video games, in turn, are no less death-obsessed than opera. ${ }^{45}$ It is largely because of this fixation that video games became a target for media hysteria. Death has as an important and paradoxical role in many video games. From platforming games (such as Super Mario Bros. (1985)), to shooting and stealth games, an avatar's death is one of the ways that a game will end. Yet, while an avatar's death may signal a ludic loss and the end of a play round, this demise is temporary - with a push of a button, the hero is resurrected. ${ }^{46}$ At the same time, inflicting death is often a ludic goal for winning (as in the games discussed above). Death is meaningful in terms of both winning/losing and in the plots of games. Macheath may escape certain death in The Beggar's Opera, but Kenway's victim, who protests that his demise is not a necessity, does indeed die, fulfilling a ludic accomplishment for players, and propelling forward the story of the game.

40 Lt. Col. Dave Grossman, quoted in Marketing Violence to Children: Hearing Before the Committee on Commerce, Science, and Transportation, United States Senate One Hundred Sixth Congress, First Session (4 May 1999), 57.

41 Steven L. Kent, The Ultimate History of Video Games (New York, 2001), 544-55. I leave it to psychologists, sociologists and game theorists to draw conclusions about any connections between games and real-world violence that may or may not exist; my argument here only extends to the consideration of popular reception.

42 Joseph Kerman, Opera as Drama, new and rev. edn (Berkeley, 1988), 205. Kerman later expressed regret for the tone of some of his criticism of Tosca, though this does not detract from the telling nature of the comment, and it remains in the revised version of his book.

43 See, for example, the testimonies of game audio practitioners Rob Bridgett, From the Shadows of Film Sound (self published, 2010), 1-10; and George Sanger, The Fat Man on Game Audio (Indianapolis, 2003), 229-37.

44 Among the most notable studies of death in opera are Catherine Clément, Opera, or, the Undoing of Women, trans. Betsy Wing (Minneapolis, 1988); Linda Hutcheon and Michael Hutcheon, Opera: Desire, Disease, Death (Lincoln, NE, 1996); and Slavoj Žižek and Mladen Dolar, Opera's Second Death (New York, 2002).

45 A recent major reference volume on video game studies dedicated a chapter to the topic of death. Karin Wenz, 'Death', in The Routledge Companion to Video Game Studies, ed. Mark J.P. Wolf and Bernard Perron (New York, 2014), 310-16.

46 On music and death in platform games, see Michiel Kamp, 'Suture and Peritexts: Music Beyond Gameplay and Diegesis', in Ludomusicology, ed. Kamp, Summers and Sweeney, 73-91. 
In Hitman, players may become directly involved in the operatic nexus of death. In several of the strategies for completing the level, players must listen and watch for the appropriate moment in the aria to pull the trigger on d'Alvade. Puccini's music scores the action of Hitman, just as in Tosca, and players have to ensure their actions fit with the musical-dramatic context of the opera. If, as Cheng suggests, levels of fiction collapse into each other in this scene, then the game action gains at least some dimension of an operatic mode (especially when standing on the stage 'in-role' as the soldier). D'Alvade dies to the same melodramatically expressive music as Cavaradossi, which here also sounds simultaneously with the player's moment of ludic triumph. In enjoying the symphonic outpouring that accompanies both death and victory, the paradoxical nexus of the pleasure we gain from the bloodthirsty action of Tosca is clear: we simultaneously want the dramatic death to occur and yet to revel in its tragedy. Game theorist Jesper Juul has compared the aesthetic experience of tragedy to the video game, since both involve concurrently held contradictory desires. In the case of tragedy, the desire is both for the 'protagonist to succeed' and yet for them to 'suffer as part of an aesthetic experience', and in games, we wish 'to avoid failure' but actively seek out an 'experience that includes partial failure.' 47 With its integration of operatic action and assassination gameplay, Hitman perhaps implies that Agent 47's story is a violent melodrama in a mould not so dissimilar to the opera.

While death is a familiar focal point in both games and operas, it is typically less meditated upon in the former. This might be why the operatic accompaniments to game violence are so striking - through the register of operatic discourse, they apply a dimension of romanticism and accentuate melodramatic aesthetics (of which more below). In The Beggar's Opera in Assassin's Creed, this is particularly evident: the killing is programmed to occur simultaneously with Mrs Peachum's air, which is specifically concerned with the romanticism of death, describing, in Steve Newman's description of the song, 'the beautiful pathos of the scaffold'.

Historical scholarship has long recognised that the varied medium of opera has had far more of a socially diverse audience than modern pop-culture representations of opera would typically admit. ${ }^{49}$ The two operas in these games are particularly notable for their challenge to simplistic images of opera's cultural address. Puccini's music has continually problematised cultural value systems, ever since its initial reception by his contemporaries as "harlot music'. ${ }^{50}$ Franklin uses Tosca to explore how 'popular veristic opera ... threatened the polarized constructions' of high and low culture. ${ }^{51}$ Mosco Carner claims that, for Puccini, opera was a site 'in which

\footnotetext{
47 Jesper Juul, The Art of Failure: An Essay on the Pain of Playing Video Games (Cambridge, MA, 2013), $42-3$.

48 Steve Newman, Ballad Collection, Lyric, and the Canon (Philadelphia, 2007), 25.

49 Joe, Opera as Soundtrack, 1-22; Ralph P. Locke, 'Music Lovers, Patrons, and the "Sacralization" of Culture in America', 19th-Century Music 17 (1993), 149-73; Derek B. Scott, 'Music and Social Class', The Cambridge History of Nineteenth-Century Music, ed. Jim Samson (Cambridge, 2002), 544-67.

50 David Kimbell, Italian Opera (Cambridge, 1991), 630.

51 Franklin, 'Movies as Opera', 88.
} 
larger, heterogeneous audiences [were] brought together to be entertained and amused. Italian opera ... addressed itself to the majority and aimed at broad appeal. ${ }^{52}$ The liminal nature of Puccini's output is encapsulated in Stephen Banfield's provocative characterisation of Puccini as a composer of 'musical drama for an audience without a connoisseur's ability to savour and concentrate'. ${ }^{53}$ While Tosca's resistance to an exclusively lofty image of opera is clearest in its reception, class differences are specifically thematised in The Beggar's Opera. Gay's work is explicitly concerned with the clash between social strata and modes of expression. Witty and satirical, it is an unashamedly populist piece, with, in Thomas Bauman's words:

[a] pungent political dimension ... [that] draws parallels between its cast of thieves, fences, whores, and venal offices from the lower reaches of London life and representatives of the city's high-end institutions - the government, the professions, and Italian opera seria. ${ }^{54}$

Both The Beggar's Opera and Assassin's Creed work to juxtapose received cultural hierarchies: the knife-wielding, thieving, murdering action is undertaken by a criminal nobleman in the setting of Covent Garden. In the opera's own words, it articulates

[the] similitude of Manners in high and low Life, that it is difficult to determine whether (in the fashionable Vices) the fine Gentlemen imitate the Gentlemen of the Road, or the Gentlemen of the Road the fine Gentlemen. ${ }^{55}$

These games challenge the assumed highbrow status of opera and assumed lowbrow status of games, suggesting a more complex and compatible negotiated relationship through their fusion in the gameworlds. Viewed one way, these dramatic moments of violence could be seen as subversive sacrilege against the high-minded and refined world of opera. But to do so is to mischaracterise and homogenise both historical operatic culture and modern operatic experience, instead putting in its place a far more recent (and disingenuous) conception of opera - one perpetuated in part by popular representations that reinforce the prestigious aura of Western art music, such as the typical film opera visit that Citron described in the quotation reproduced earlier.

These games neither conform to the trope of exultantly rarefying opera, nor do they articulate a viewer-distancing aesthetic of 'detachment', such as Citron argues is evident in Quantum of Solace. Instead, we are asked to consider the similarity between the stage action and the game as a whole. This is directly addressed in Assassin's Creed III. Throughout the game, players are prompted to consult an in-game database of historical information, so they may better understand the world

52 Mosco Carner, Giacomo Pucini: Tosca (Cambridge, 1985), 75.

53 Stephen Banfield, 'Music, Text and Stage: Bourgeois Tonality to the Second World War', in The Cambridge History of Twentieth-Century Music, ed. Nicholas Cook and Anthony Pople (Cambridge, 2004), 100. The diverse appeal of Puccini's music was a conscious part of his artistic agenda: Mosco Carner, Puccini: A Critical Biography (New York, 1959), 235; and Kimbell, Italian Opera, 634.

54 Thomas Bauman, 'The Eighteenth Century: Comic Opera', in The Oxford Illustrated History of Opera, ed. Roger Parker (Oxford, 1994), 96-7.

55 Gay, Beggar's Opera, Scene xvi, 82-3. 
in which they play. Entries in this irreverent encyclopaedia include the Theatre Royal and The Beggar's Opera. The commentary on the latter concludes:

The Beggar's Opera was accused of being a 'base form of entertainment' and - because its main characters were criminals - accused of causing increase in crime. It's nice to see that criticism isn't just for movies and video games. Bloody opera - corrupting our kids...

The games described here embrace, and argue for, the visceral appeal and entertaining nature of (at least some) opera. Representing opera in games, especially in the style found in Assassin's Creed and Hitman, is technically tricky and not undertaken lightly - and thus likely implies a sincere belief by the gamemakers in its significant value for the game experience. In applying an operatic frame to these moments in games, the similar thrills, spectacles and high-stakes emotion of both media are mutually recognised and reinforced, even if the received wisdom that perpetuates 'the great divide ... between high art and mass culture' would have us believe otherwise. ${ }^{56}$ To use Yvonne Noble's phrase, when she describes the parallels of high and low life drawn in The Beggar's Opera, these instances of opera in games are 'bringing out the more submerged likenesses' between the two media. ${ }^{57}$

\section{Melodramatic divas}

Final Fantasy VI (1994) includes what is probably the most well-known example of staged opera in video games. In the game, the player controls a band of rebels who seek to overthrow a dictatorship. As part of a plan to gain access to an airship, one of the group, a hardened military general named Celes, must impersonate an opera singer scheduled to perform an opera called Maria and Draco. She takes on the starring role of Maria (Fig. 3). Prior to the opera performance, players must read a copy of the libretto for Maria's showstopping aria and memorise the text. To progress through the aria in performance, the gamer chooses the correct lyrics from the multiple choices presented to them. During the 'interlude' between verses, the player also directs Celes to engage in a dance with another actor, and follow some basic stage directions (throwing a prop bouquet off the castle set's ramparts). After the aria, the focus splits between the continuing opera, in which Maria/Celes plays only a minor role, and the off-stage heroes who learn that a villain plans to ambush them imminently. Ultimately, they battle the enemy on the stage, interrupting the opera, before departing on the airship.

Because of the technological limitations of the Super Nintendo Entertainment System console for which Final Fantasy VI was created, Celes does not gain an acoustically recorded voice in her aria, but rather a synthesised open vowel sound that acts as a vocalise. The contour of the melody approximately follows the libretto phrases that are presented as on-screen text to the viewer.

56 Andreas Huyssen, After the Great Divide: Modernism, Mass Culture, Postmodernism (Bloomington, 1986), viii.

57 Yvonne Noble, 'Introduction: The Beggar's Opera in Its Own Time', in Twentieth-Century Interpretations of The Beggar's Opera, ed. Yvonne Noble (Englewood Cliffs, 1975), 6. 

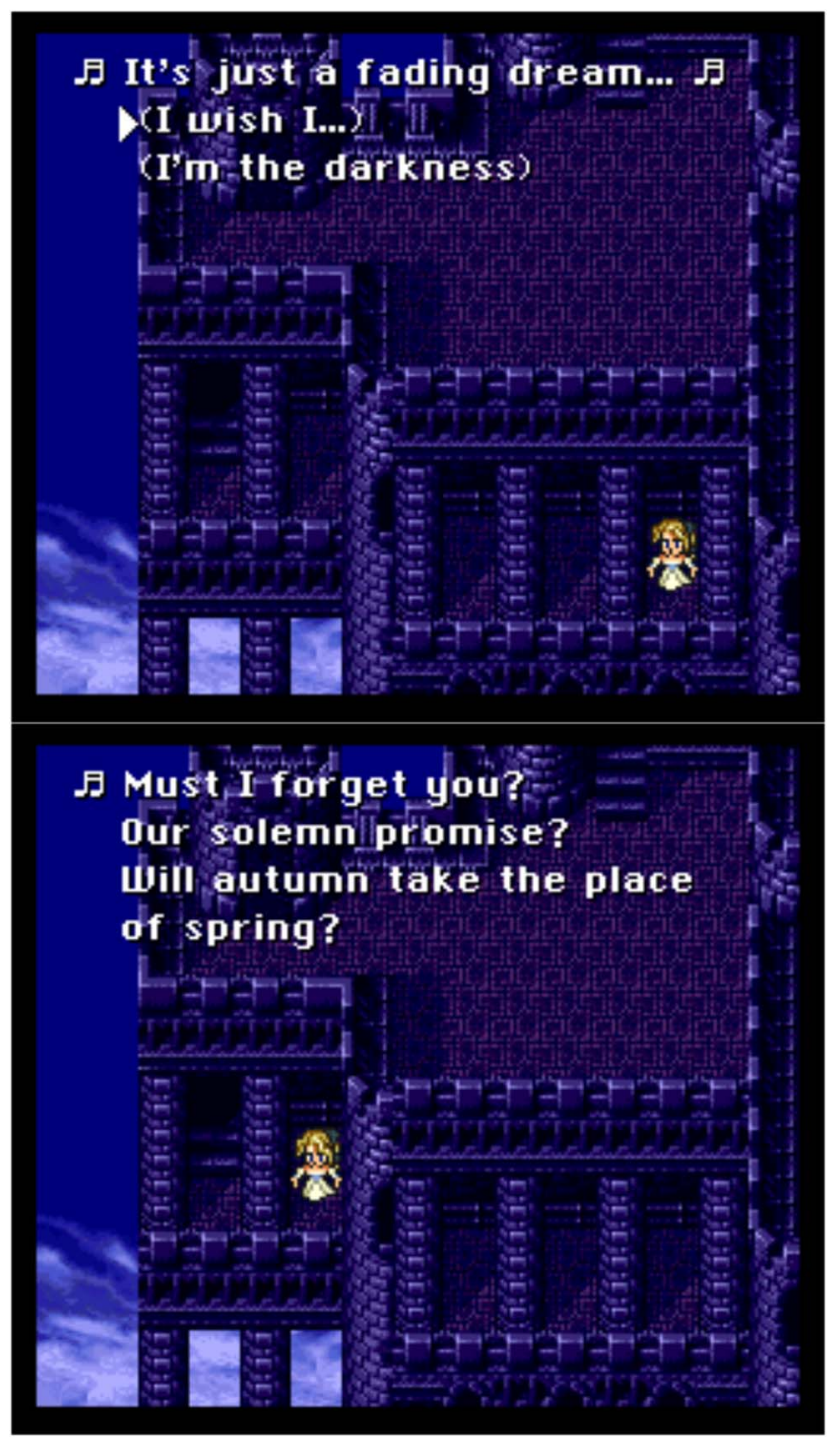

Fig. 3: Celes in Maria and Draco in Final Fantasy VI. At certain points in the aria, the player must choose the correct next line of the libretto from the two options presented (top) for Celes to continue to sing (bottom). Screen capture by Tim Summers, 13 August 2016.

Maria's aria was written by the game's composer, Nobuo Uematsu. Both William Cheng and Ryan Thompson argue for the similarity of this aria to Italian opera. ${ }^{58}$ As Cheng describes:

The aria's form resembles a modified strophic song with instrumental introduction, interlude, and coda ... above rippling arpeggios[, t]his melody's gentle arching

58 Cheng, Sound Play, 63-74. Ryan Thompson, 'Operatic Conventions and Expectations in Final Fantasy VT, paper presented at the 8th Conference of Music and the Moving Image, New York, 31 May 2013. 
contours, internal phrasal symmetries, steady harmonic rhythms (typically one chord change per measure), and consonant tonal language evoke the Italianate cantilena writing of Vincenzo Bellini, Gaetano Donizetti, and other early Romantics. ${ }^{59}$

The sequence has become a significant touchstone in video game culture. It is particularly notable for the effusive reports of emotional responses that typically accompany its discussion in casual and journalistic discourse. ${ }^{60}$ Even though the sequence after the aria is more obviously comic, players nevertheless highlight the main aria as a profoundly affecting experience, the memory and emotional potency of which lasts long after the gameplay has finished. Cheng ascribes this sequence's popularity to the technological limitations of Celes's sung 'voice', but characterises the relationship between opera in games in rather dissonant terms:

When opera crops up in games, it is hence liable to come across as a foreign presence, a rarefied display that agitates a game's aesthetic and narrative frames. Opera's curious presence in gameworlds offers a means of thinking through additional tensions between ... high and low cultures. ${ }^{61}$

Cheng writes of tensions and juxtapositions. Accordingly, he describes the Final Fantasy VI opera as a 'performance [that] stands for high musical culture. ${ }^{62}$ As suggested in the discussion of Hitman and Assassin's Creed, however, it may be useful to understand the synthesis of games and opera as revealing rather more compatible aesthetic priorities. Perhaps it is the aptness of opera as an expressive mode that helps to make such moments so striking. Rather than an 'agitating' 'foreign presence', it may be mutual congruity that contributes to these scenes becoming aesthetically successful and, as in Final Fantasy VI, well loved by players. ${ }^{63}$ Part of this symbiosis between opera and games might be found in a kind of expression that can be characterised as melodramatic.

Rather than using the term 'melodrama' to refer specifically to a narrow set of specific historical works, such as the Victorian stage melodrama or the German melodrama, instead - in the tradition of Peter Brooks, Linda Williams, Sarah Hibberd and others - I mean to refer to an aesthetic mode that extends from the corpus of melodramas into a multitude of art forms. ${ }^{64}$ James L. Smith, for example, characterises melodrama in terms clearly compatible with a video game:

[T] he undivided protagonist of melodrama has only external pressures to fight against ... It is this total dependence upon external adversaries which finally separates

59 Cheng, Sound Play, 71.

60 Cheng, Sound Play, 74-6.

61 Cheng, Sound Play, 63.

62 Cheng, Sound Play, 79.

63 Cheng, Sound Play, 74-5; See also Chris Kohler, Power-Up: How Japanese Video Games Gave the World an Extra Life (Indianapolis, 2005), 118; Thompson, 'Operatic Conventions'. For one example among many of the scene's reception, see Zachary Ryan, 'Top 100 Unforgettable Video Game Moments: 43. The Opera Scene', IGN.com (15 September 2017), uk.ign.com/lists/top-100-videogame-moments/43.

64 Peter Brooks, The Melodramatic Imagination (New Haven, 1995); Hibberd, 'Introduction', in Melodramatic Voices, ed. Sarah Hibberd (Farnham, 2011), 1-11; Linda Williams, 'Melodrama Revised', in Refiguring American Film Genres, ed. Nick Browne (Berkeley, 1998), 42-88. 
melodrama from all other serious dramatic forms ... Characteristically, melodrama presses its own extreme conflicts to extreme conclusions. Only three are possible, for when an undivided protagonist opposes a hostile world ... the result must be stalemate, victory or defeat. ... Triumph, despair and protest are the basic emotions of melodrama, and the art of working each to its highest pitch occasions the catharsis of the form. ${ }^{65}$

Or, put in terms of a game, the player's avatar works single-mindedly against external forces or opponents in extreme conflicts, with the outcome of winning, losing or achieving a tied finish. More recently, Ben Singer has outlined five 'basic features or constitutive factors' of melodrama:

1. Non-classical [illogical] narrative structure.

2. Moral polarisation.

3. Sensationalism.

4. Pathos.

5. Overwrought emotion. ${ }^{66}$

Narrative video games could be usefully mapped onto such a list:

1. The often arbitrary rule-based structures of games. ${ }^{67}$

2. The clear protagonist-antagonist structure of ludic game action.

3. The goal of designers to maximise experiential sensation for players.

4. The player's identification with avatar characters and interaction with nonplayable characters.

5. The extremes of emotion that come with winning and losing.

Hibberd, meanwhile, also argues for Singer's qualities as 'characteristic of operas', 68 while Jeremy Tambling discusses the typical inclusion of opera in post-1970 film as part of a melodramatic aesthetic. When he claims that 'the medium of film stands to gain from the operatic', he argues it is partly because 'opera, melodrama and cinema [can be brought] into a constellation where they work analogously in terms of pleasure, and in the return of an ideal excess' ${ }^{69} \mathrm{~A}$ similar situation appears to be the case in the games described here, manifested through the presentation of staged opera as a moment of sincere expression.

65 James L. Smith, Melodrama (London, 1973), 8-9.

66 Ben Singer, Melodrama and Modernity: Early Sensational Cinema and Its Contexts (New York, 2001), 44-9.

67 This issue of narrative illogicality driven by ludic concerns is highlighted by game theorist Jesper Juul, when he asks the rhetorical question, 'Why does Mario have three lives?' Jesper Juul, HalfReal: Video Games Between Real Rules and Fictional Worlds (Cambridge, MA, 2005), 123.

68 Hibberd, 'Introduction', 3.

69 Jeremy Tambling, Opera, Ideology and Film (Manchester, 1987), 65. In parallel scholarship, Marcia Landy describes melodrama as a component of her notion of an operatic aesthetic in film and Peter Brooks has argued that 'opera in the nineteenth century develops, realizes ... tendencies of melodrama': Landy 'Opera, Cinema, Melodrama, and History: The Case of Italian Cinema', The European Legacy 1 (1996), 1597; Brooks, 'Body and Voice in Melodrama and Opera', in Siren Songs, ed. Mary Ann Smart (Princeton, 2000), 120-1. 
In Final Fantasy VI, when Celes/Maria sings of her profound emotional despair in a sequence that clearly trades on visual and sonic spectacle, we are encouraged to marvel at this moment of ostentatious expressive display. The player is therefore brought into engagement with the opera, through the necessity of paying close attention to the operatic materials. While Celes is shown to be playing a part in the opera, and the sequence following the aria is distinctly light-hearted, there is a musical process that makes the case for opera, despite its overt artifice, as somehow speaking to an emotional truth.

The main playable characters in Final Fantasy VI are introduced to the gamer when they each make their debut in the plot. When a new protagonist is encountered, the action in the world is paused, and against a black screen, the character is shown with a brief biographical description. When Celes is introduced, for example, the text reads: 'A Magitek knight forged by the Empire and tempered in battle. None have ever truly known the woman beneath the general's guise.' Protagonists are at the same time given a non-diegetic musical theme. Because of the small pixelated characters and aphoristic textual description, the music plays a large part in defining the characters for the player. This theme recurs at moments throughout the game that are particularly pertinent to that character's story. Celes, however, is an exception to this pattern. When she is introduced, she does not have a personalised musical accompaniment. Instead, later in the game, after the opera sequence, she adopts the melody of Maria's aria as her musical theme. ${ }^{70}$ Celes's introductory biography refers to the enigmatic quality of the character we hear no music to tell us more about her, until her operatic manifestation reveals 'the woman beneath the general's guise'. In supplying Celes with her musical identity for the game, the opera is presented as a moment of honest expression for the character.

Final Fantasy VI is by no means the only game to use staged opera as a melodramatic moment that represents personal revelation through musical performance. Parasite Eve, for instance, opens with an opera visit. The beginning of any game is crucial for establishing its tone, fictional environment and premise; Parasite Eve uses staged opera to set out its aesthetic stall. We join police officer Aya Brea on her romantic date at Carnegie Hall, where an unnamed opera is being performed. On a castle set, a prince pleads with his father to allow him to marry a woman named Eva, also present on the stage, dressed in a long crimson gown. The king is unwilling, because he believes Eva to be 'evil' and that she causes the death of those who 'succumb to her beauty'. After the king orders Eva's execution through burning at the stake, Eva starts to sing an aria. Much like the number from Final Fantasy VI, it is a slow, lyrical piece with repetitive vocal figures in an Italianate mould. In simple triple time, a vocalise part sounds a simple minor-mode melody accompanied by an arpeggiating harp and strings (sustaining chords with the harmonic rhythm of one chord per bar). ${ }^{71}$

70 The music is particularly foregrounded at another melodramatic moment in the game when Celes, overcome with despair, attempts suicide while the music plays. For discussion of this episode see Cheng, Sound Play, 81-3.

71 The soundtrack album for the game names the aria as 'Se il mio amore sta vincino', from the opera La mia verita (again referring to notions of expressive truth). The album provides a version of the aria with an Italian text, sung by soprano Judith Siirila Paskowitz. She is credited in the liner notes 
Parasite Eve was made for the Sony PlayStation, which had a limited capacity to show high-quality video clips. At the end of the first ten-bar section of the aria, and on a sustained imperfect cadence, the game suddenly changes from a lowquality and blurry visual style into a glossy and detailed video for the rest of Eva's aria. Now, we see our diva rendered clearly and in close-up, with expressive bodily and facial gestures during the ecstatic moment of operatic performance. The camera moves around her and zooms in on her face. In an unexpected close-up on the singer's eyes, we understand that she sees Aya in the audience. As they meet each other's gaze, Eva's eyes narrow and change colour. Then, as the soloist looks at the other actors on the stage, they begin to spontaneously combust. Apparently unperturbed, she returns to facing out into the auditorium, where members of the audience also ignite. Soon panic sets in, with bodies falling from the balcony and a stampede for the exit. The flames spread to engulf the building and people within. Yet she continues to sing. At the end of the sequence, Eva stands triumphant alone onstage, still singing, framed by a proscenium arch of flame (Fig. 4).

The rest of the game follows Aya's struggle to defeat the villainous creature known as 'Eve', a megalomaniac sentient parasite that has taken over the singer's body. After the singer had contracted the parasite, it remained dormant for a decade before this moment of operatic performance caused 'Eve' to overtake her host and begin her reign of terror.

Parasite Eve's arresting opening can clearly be understood as melodramatic in its comic-horrific excess, the spectacle of high-quality images, an unusual narrative logic, the topic of grisly death and the grandiose announcement of the chief villain of the game. As in Final Fantasy VI, it is a moment at which operatic expression gives voice to reveal an inner nature; a claim ultimately made twice. At the end of the game, with Eve defeated, Aya returns to the hall to watch the same opera (albeit with a different singer as Eva). The scene plays out as before, though without any spontaneous combustion. A lieto fine, we hope. Midway through this same aria, however, another biological mutation begins, this time in the bodies of the audience, causing their eyes to turn red. The final image is from the perspective of the singer, watching the softly glowing red eyes in the darkened auditorium. As the singer concludes the number in the relative major key, the game finishes with this shocking ending. Once again, it is this operatic performance that has the power to prompt the biological change.

Both Parasite Eve and Final Fantasy VTs opera scenes are exaggerated visual-sonic spectacles, which are especially striking given the technological limitations at hand. These sequences stretch any sense of logical causality, but nevertheless serve as important moments of expression for their characters, thereby uniting (as Hibberd puts it) 'meaning and sensation', extravagant theatricality and emotionalism. $^{72}$

not by voice type or as a singer, but as a 'Diva'. Yoko Shimomura, Parasite Eve Original Soundtrack SQEX 10222 3 (1998).

72 Hibberd, 'Introduction', 8. 


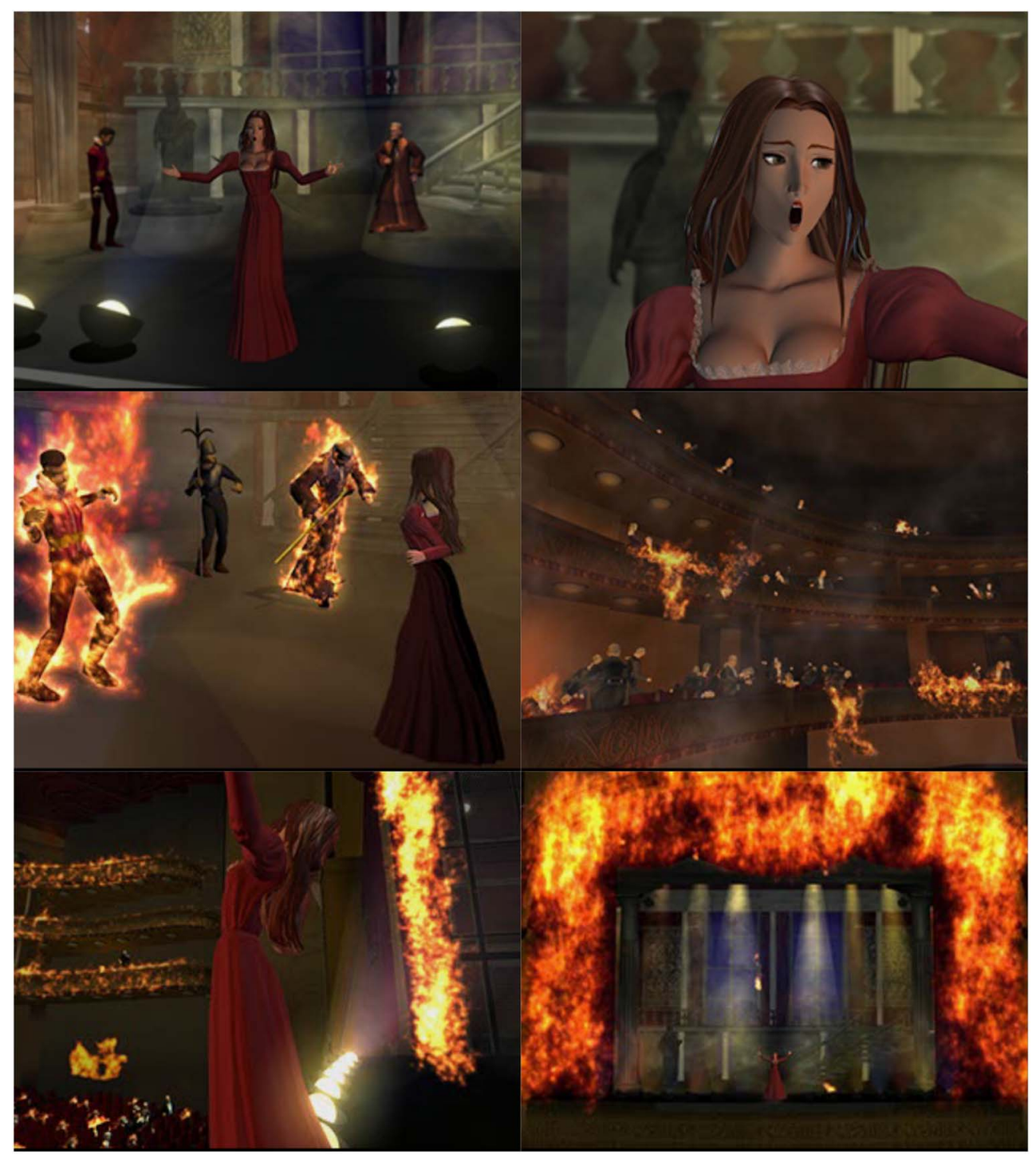

Fig. 4: Eva's aria in the opening scenes of Parasite Eve. Screen capture by Tim Summers, 13 August 2016.

Beyond the melodramatic qualities of the arias, we should recognise the gendered aspects of the presentation. ${ }^{73}$ Parasite Eve's plot is dominated by women: the narrative concerns Eve, Aya and Aya's female relations. Men are regulated to secondary characters. Unlike Parasite Eve, in Final Fantasy the player engages both male and female avatars, though at the moment of the opera, gamers must play as Celes. Even

73 While opera singers are typically caricatured when encountered outside the opera house (as in the stereotypically plump opera singers that are found in Ghostbusters (2009), No-One Lives Forever (2000) and The Haunted Mansion (2003)), when opera is staged, the depiction tends to be more sincere. 
though these games reinscribe the 'Western tradition of gendering vocal music as a feminine prerogative, ${ }^{74}$ the context of the game medium may be significant for the discussion of gender.

It has been well recognised that video games are problematic in terms of gender equality, both in the games and in the surrounding culture. ${ }^{75}$ Research has repeatedly documented that male characters dramatically outnumber female characters, that these women are more likely to be presented as having little or no agency, and that they are 'significantly more likely to be shown partially nude, featured with an unrealistic body image, and depicted wearing sexually revealing clothing. ${ }^{76}$

The two games discussed here both present opera performances as moments of female agency and expression (of one kind or another), and encourage interpretation from a female subject position. Final Fantasy VI makes an effort to show compatible diverse modes of femininity with Celes, who protests at one moment, I'm a general, not some opera floozy!' Neither are Celes or Eve simple caricatured divas; they are central characters that the player spends many hours coming to know and understand. When these characters sing, they do so as part of episodes that aim to influence player emotion. ${ }^{77}$

74 Joe, Opera as Soundtrack, 121.

75 Much discussion of sexism in games has used the heroine of the Tomb Raider games, Lara Croft, as a focal point. See, for example, Diane Carr, 'Playing With Lara', in ScreenPlay: Cinema/Videogames/ Interfaces, ed. Geoff King and Tanya Krzywinska (London, 2002), 171-80; Amanda du Preez, 'Virtual Babes: Gender, Archetypes and Computer Games', Communicatio 26 (2000), 18-27; Helen W. Kennedy, 'Lara Croft: Feminist Icon or Cyberbimbo?', Game Studies 2 (2002), gamestudies.org/ 0202/kennedy/; Esther MacCallum-Stewart, “'Take That, Bitches!” Refiguring Lara Croft in Feminist Game Narratives', Game Studies 14 (2014), gamestudies.org/1402/articles/maccallumstewart; Maja Mikula, 'Gender and Videogames: The Political Valency of Lara Croft', Continuum 17 (2003), 79-87. See also Carrie Heeter, 'Femininity', in The Routledge Companion to Video Game Studies, ed. Wolf and Perron, 373-9; Jennifer Jenson and Suzanne de Castell, 'Theorizing Gender and Digital Gameplay: Oversights, Accidents and Surprises', Eludamos Journal for Computer Game Culture 2 (2008), 15-25; Benjamin Paaßen, Thekla Morgenroth and Michelle Stratemeyer, 'What is a True Gamer? The Male Gamer Stereotype and Marginalization of Women in Video Game Culture', Sex Roles 76 (2017), 421-35; Magdala Peixoto Labre and Lisa Duke, "Nothing Like a Brisk Walk and a Spot of Demon Slaughter to Make a Girl's Night": The Construction of the Female Hero in the Buffy Video Game', Journal of Communication Inquiry 28 (2004), 138-56; and Cosima Rughiniș et al., 'Three Shadowed Dimensions of Feminine Presence in Video Games', DiGRA/FDG '16 - Proceedings of the First International Joint Conference of DiGRA and FDG 13 (2016), www.digra.org/wp-content/uploads/digitallibrary/paper_321.pdf.

76 Edward Downs and Stacy L. Smith, 'Keeping Abreast of Hypersexuality: A Video Game Character Content Analysis', Sex Roles 11-12 (2010), 721. See also Charles Dickerman, Jeff Christensen and Stella Beatríz Kerl-McClain, 'Big Breasts and Bad Guys: Depictions of Gender and Race in Video Games', Journal of Creativity in Mental Health 3 (2008), 20-9; Karen E. Dill and Kathryn P. Thill, 'Video Game Characters and the Socialization of Gender Roles: Young People's Perceptions Mirror Sexist Media Depictions', Sex Roles 57 (2007), 851-64; Theresa Lynch, Jessica E. Tompkins, Irene I. van Driel and Niki Fritz, 'Sexy, Strong, and Secondary: A Content Analysis of Female Characters in Video Games across 31 Years', Journal of Communication 66 (2016), 564-84; and Dmitri Williams, Nicole Martins, Mia Consalvo and James D. Ivory, 'The Virtual Census: Representations of Gender, Race and Age in Video Games', New Media and Society 11 (2009), 815-34.

77 Carolyn Abbate famously suggested the performative empowerment of women in opera through the potential ability of a singing diva to unseat a male determining author in place of female power. As she puts it: 'Visually, the character singing is the passive object of our gaze. But, aurally, she is resonant; her musical speech drowns out everything in range, and we sit as passive objects, battered by that voice. ... A singer, more than any other musical performer, enters into that Jacobin 
These opera moments, however, remain problematic. Celes, for instance, we might read as reinscribing the trope of the emotional woman, escaping masculine stoicism through feminising music. Both Celes/Maria and Eva/Eve wear low-cut costumes, even if the dresses are prudish in comparison with the typical attire of women in games. While Eve does not serve as a femme fatale in the game, Eva's role in the opera is certainly characterised as such. ${ }^{78}$ Nevertheless, we might propose that these scenes have the potential to complicate the simplistic representations found elsewhere, as the pixelated divas demonstrate their skill and agency in ways that are clearly meant to be affecting for the gamer. ${ }^{79}$

Final Fantasy VI and Parasite Eve, then, use staged opera arias as part of a melodramatic aesthetic of excess. Rather than demonstrating an oppositional tension between opera and games, this complementary synthesis highlights once again the potential connections between the two genres. Opera is in these examples presented not as caricature, but as an expressive, emotionally affecting and melodramatic medium.

\section{Wagner's werewolves}

So far I have argued that staged opera in games serves to present a vision of opera that emphasises its thrilling, sensationalist and gripping qualities. In the process, such instances avoid portraying opera in terms of high-minded abstraction, but instead elucidate the similarities of the two media at hand. To develop these themes further, I turn to a final example, Gabriel Knight 2: The Beast Within (1995). This game represents what is likely the most extensive meditation upon opera in video games to date.

The Beast Wittin is a supernatural thriller: a point-and-click adventure game, in which player-controlled characters are directed by clicking on locations and items in the diegesis. Much of the storytelling occurs through exploration and engaging in extensive conversation with other characters.

In modern-day Germany, American crime novelist Gabriel Knight has retreated to Bavaria to work on his new book. While there, he is called upon to investigate a spate of recent murders. The player alternates between Knight's investigation in Munich and the parallel efforts of his assistant, Grace Nakimura, in locations across Bavaria. As the plot develops, it becomes increasingly intertwined with the life of Ludwig II and the work of Richard Wagner. ${ }^{80}$

uprising inherent in the phenomenology of live performance and stands before us having wrested the composing voice away from the librettist and composer who wrote the score.'

Carolyn Abbate, 'Opera; or, the Envoicing of Women', Musicology and Difference, ed. Ruth A. Solie (Berkeley, 1993), 254.

78 I thank one of the anonymous reviewers for their assistance in developing this thinking.

79 For a similar complex problem of female power enacted through vocal performance, see Jeongwon Joe's discussions of The Fifth Element (Opera as Soundtrack, 130-6) and Blue Velvet ('The Cocktail Siren in David Lynch's Blue Velvet', in Music of the Sirens, ed. Linda Austern and Inna Naroditskaya (Bloomington, 2006), 349-70).

80 For more on film and Wagner's music in a variety of different settings, see David Huckvale, 'The Composing Machine: Wagner and Popular Culture', in A Night in at the Opera, ed. Jeremy Tambling (London, 1994), 113-43; and essays in Joe and Gilman, eds., Wagner and Cinema. 


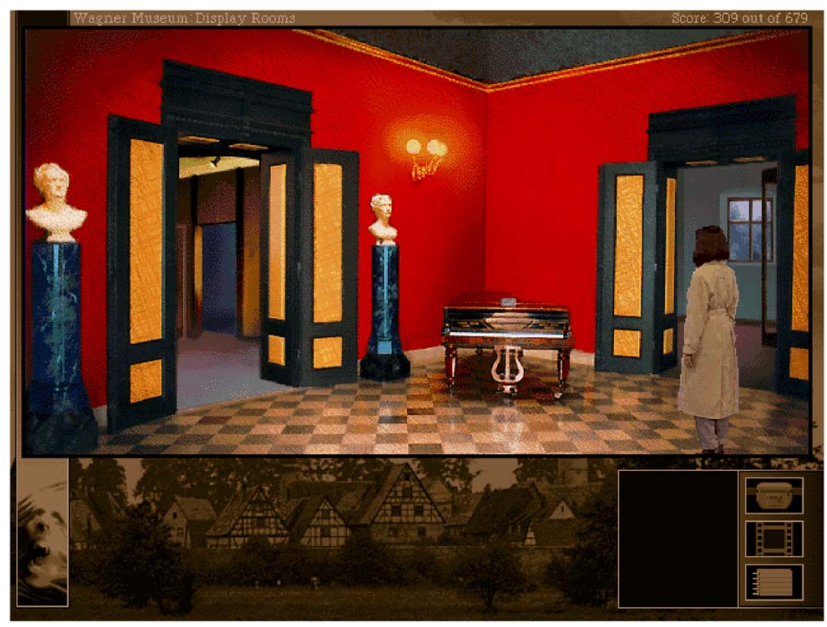

Fig. 5: Grace at Wahnfried in The Beast Within. Objects in the room, such as the piano and busts, may be clicked on for close-up inspection and additional information. Screen capture by Tim Summers, 18 July 2016.

Grace comes to suspect that the attacks are the work of a werewolf. Researching historical precedent for the phenomenon, she finds evidence to suggest that Ludwig II had a close connection with such a supernatural being. To discover more about the king, she visits the museum at Herrenchiemsee. ${ }^{81}$ In the museum, the game makers present historically accurate information and artefacts to the player, but begin to thread a fictional seam into the sources through additions and alterations. ${ }^{82}$ A mysterious fictional letter from Ludwig is shown that commands preparations begin for a new Wagner opera to be staged in Munich in $1882 .{ }^{83}$ Intrigued, Grace travels to Bayreuth, to Wahnfried, to find out more.

Since The Beast Within uses high-quality images, Wahnfried can be depicted to players with a reasonable degree of visual fidelity. Figure 5, for example, shows Grace standing in Wahnfried, complete with Wagner's Breitkopf \& Härtel piano, a sometime resident of this room. To progress, players must view close-ups of artefacts from Wagner's life and, in the process, become familiar with his biography.

81 A letter from Ludwig to Elizabeth of Austria, dated 3 July 1867, is reproduced in the game, but dated 3 July 1863. Original letter in Desmond Chapman-Huston, Bavarian Fantasy: The Story of Ludwig II (London, 1955), 133.

82 In this virtual museum, the game recreates famous paintings related to Ludwig, including the wellknown 1880 painting by Richard Wenig of Ludwig on a night-time sleigh ride. It also accurately reproduces some of Ludwig's letters and artefacts such as Ludwig's death mask. Ludwig's historical riding accident is fictionalised as the moment at which he was bitten by the werewolf. ChapmanHuston, Bavarian Fantasy, 166.

83 Ludwig had, however, at this time demanded of Wagner a staging of Parsifal at Munich, the same city where, in The Beast Within, Ludwig and Wagner planned Der Fluch des Engelhart to be performed. Martin Gregor-Dellin and Dietrich Mack, trans. and ed., Cosima Wagner's Diaries, Volume II, 1878-1883 (London, 1980), 964, 967, 995, 1001. 
Throughout, fiction and historical accuracy are carefully intertwined. On the Lohengrin-Schreibtisch, Grace finds correspondence by Wagner from September 1881 about acoustics in the Wittelsbach theatre in Munich. She also finds letters between Ludwig and Wagner about this new performance. Confused as to why, with Bayreuth built, Wagner would be concerned with another theatre, she continues to Neuschwanstein.

Grace moves through virtual replicas of several locations at Neuschwanstein, examining the Wagnerian murals and swan motifs. She also finds that the famous Parsifal scenes around the grand Singers' Hall had been replaced in 1882 with images that depict a new story featuring wolf imagery. As Grace's tour guide audio tape describes, 'While all of the other rooms in the castle show scenes from Wagner operas, the scenes in this room are not from any opera that anyone can identify.' It becomes clear to the player that the new plot is that of a 'lost' Wagner opera. Returning to Bayreuth, Grace is shown Cosima's diary which, in fictional entries, refers to a new, completed, project for the king.

Ludwig and Wagner are presented in extraordinary detail to the player. No flippant contrivance of the plot, this is a concerted effort to ground a fantastical story in historical reality. Since gamers must examine every object and noticeboard within the virtual museums to progress through the game, they cannot avoid being given an education about Wagner and Ludwig. The game creators, meanwhile, are conscious of the potential problem of mixing fiction with historically accurate information. The game's credits, which are shown at the conclusion of the game, or accessed from the main menu without completing the game, begin with a notice:

The Beast Within is a fictional story. However, many of the settings and historical figures are based on real life. You can learn more about King Ludwig II of Bavaria and Richard Wagner at your local library. Historical dates and facts presented in this fictionalization are not necessarily accurate.

Grace comes to understand that Ludwig II's mentally unstable later years were the result of a werewolf attack. Since Wagner's music provoked a physical response in Ludwig, the monarch asked Wagner to create an opera that would help to cure Ludwig's condition and/or destroy his werewolf betrayer. Grace eventually uncovers the manuscript of the opera, hidden at various locations in Neuschwanstein. Gabriel identifies the modern-day werewolf in Munich and is himself bitten (something of an unhealing Amfortas wound, draining his energy, but not killing him). To save Gabriel and capture the werewolf, Grace mounts a production of the opera, whose title is revealed as Der Fluch des Engelhart, at the Wittelsbach theatre. ${ }^{84}$ She invites the suave werewolf villain (von Glower) to the opera.

84 In the same way that Bayreuth is shown earlier in the game, the Wittelsbach theatre at the Munich Residenz is (re)created for gamers. A minor plot point also correctly informs the player that the current theatre was not the same building that stood contemporary with Wagner, but was a rebuilt theatre, following its destruction in World War II. 


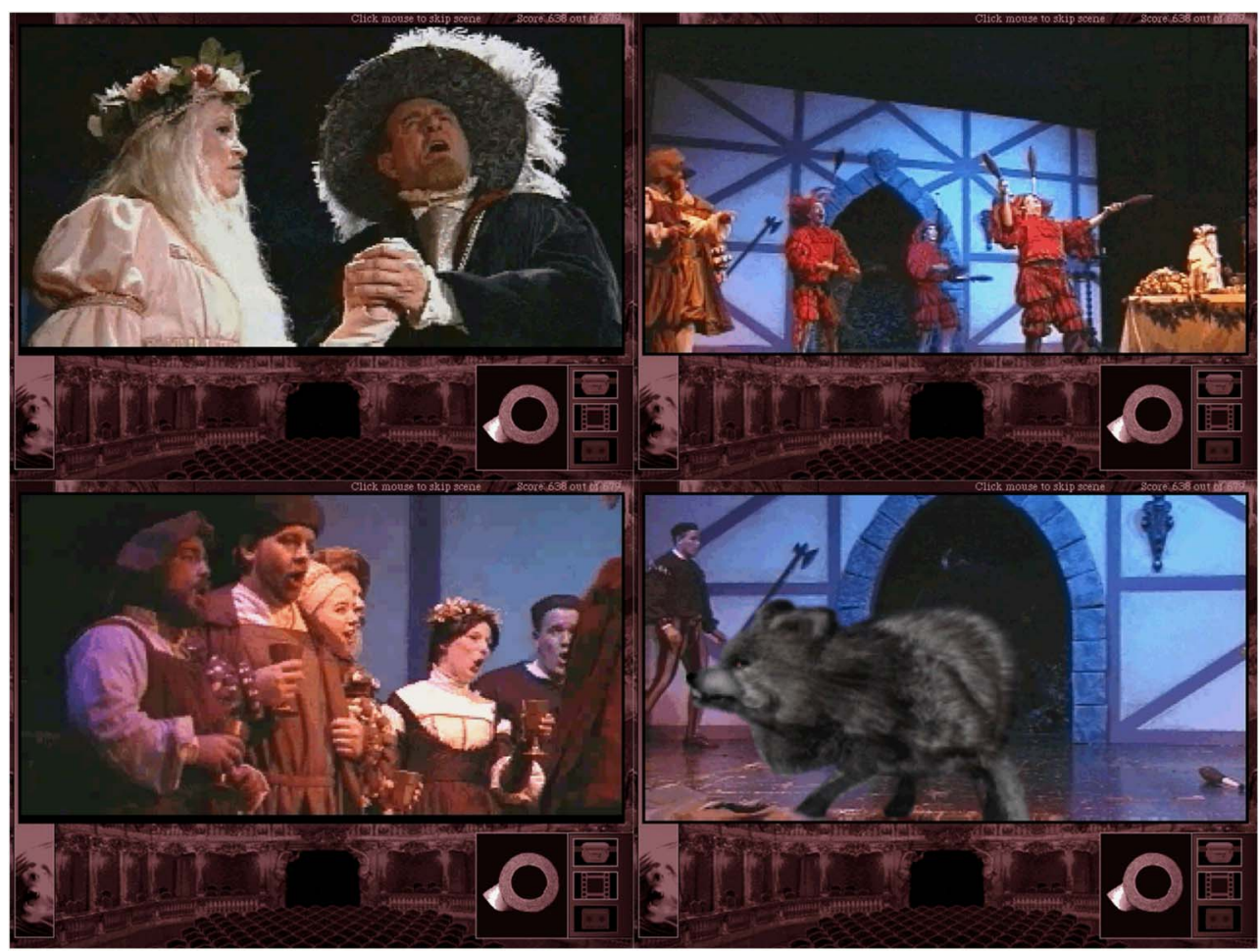

Fig. 6: Scenes from Der Fluch des Engelhart in The Beast Within, showing Hildegunde and the Baron, the minstrel troupe, the chorus, and Gabriel Knight's transformation. Screen capture by Tim Summers, 15 August 2016.

During the third act of the opera, the cumulative, irresistible effect of the music and staging is meant to force the murderous von Glower to change into a werewolf and reveal his nature to the public. The player reads a synopsis of the entire opera before it is staged, though only the third act is directly depicted. The crucial part of the opera is shown to the gamer in full video, similar to a filmed operatic production, and lasts approximately ten minutes (see Fig. 6). Making full use of the space for video/sound provided by the then-new standard of CD-ROM, the singers are acoustically recorded and, though accompanied by a synthesised orchestra, sing a full German text.

This opera sequence, with a set, costumes, chorus and two main soloists, was a complicated and costly affair. The game's producers would not have expended the resources on staging the opera if it was not thought worth the considerable investment required, nor if they believed that it had the potential to alienate players. The sequence was not undertaken lightly; the scale and production values indicate the producers' confidence in the value of this operatic moment.

Like Maria and Draco and the unnamed opera in Parasite Eve, Der Fluch des Engelhart qualifies as what Francis Rizzo calls a 'shadow opera': newly written 
operatic scenes for inclusion in a film. ${ }^{85}$ Here, the opera was written by Robert Holmes, composer for the Gabriel Knight series, to a libretto by Jane Jensen, the game's designer and writer. ${ }^{86}$ The staged scene depicts the first part of the third act of the opera.

The entire scene involves an aria, a duet and a longer ensemble passage that includes the chorus and a few minor solo singing roles. ${ }^{87}$ The opera's plot is convoluted, but essentially centres on heroine Hildegunde's love for Engelhart, who has been cursed with werewolfery by an evil Baron who wants Hildegunde for himself. While showing a variety of vocal forces, the scene also demonstrates a diversity of tone, including dramatic action, comedy and heartfelt soliloquising. The musical material for the scene begins as a respectable pastiche of Wagnerian music, especially in the initial aria and duet, which ape the long melodic lines and sustained accompaniment textures typical of his writing. The transformation sequence is less convincingly Wagnerian, not least because of the integration of long descending string glissandi. Nevertheless, taken as a whole, the scene is broadly similar to Wagner's musical style - the source of the pastiche is distinctly clear and the musical resemblance obvious. (Some artistic licence is perhaps to be fairly granted here; after all, this was supposedly Wagner's late style.) For the opera neophyte, this is a reasonable broad-strokes representation of the soundworld one might expect to encounter in a Wagnerian opera. Wagner's music does indeed prove to be as powerful as promised. During the scene, both von Glower and Knight undergo transformations into werewolves, at the prompting of the music.

This depiction of the physiological power of Wagner's music has much in common with Nietzsche's famous later criticism of the composer's work. When he writes of Wagner's music as producing the 'overexcitement of the nervous mechanism' with 'physiological degeneration', 'hypnotism by means of music', and describes youths who become 'rigid, pale, breathless' with Wagner 'master over them' because his 'persuasive power ... topples every taste, every resistance, ${ }^{88}$ he could be describing the transformations that occur to von Glower and Knight during Der Fluch des Engelhart (Fig. 7).

85 Francis Rizzo, 'Shadow Opera', in Film Music, ed. James L. Limbacher (Metuchen, NJ, 1974), 166-72.

86 Corey Sandler, The Beast Within: Official Player's Guide (San Mateo, CA, 1995), 169.

87 The action of the scene is as follows: it is the wedding feast of Hildegunde (the heroine) and the evil Baron who is secretly a werewolf. Hildegunde has been unwillingly married to the Baron. She sings of her sorrow in an aria before the Baron attempts to cheer her up. The wedding entertainment arrives in the form of a troupe of jesters. After a comedic interlude with the chorus of villagers, one of the jesters is revealed to be Hildegunde's true love, Engelhart, who the Baron has cursed with werewolfery. Engelhart transforms into the wolf in front of the astonished wedding party. The Baron urges the villagers to attack the wolf, but they do not turn against Engelhart. In his rage, the Baron reveals his nature and also transforms into a werewolf. He chases Engelhart, meaning to kill him. Both wolves exit, pursued by the throng of villagers, ending the scene.

88 Friedrich Nietzsche, The Case of Wagner, trans. Walter Kaufmann (New York, 1967), 166; 169-72. 


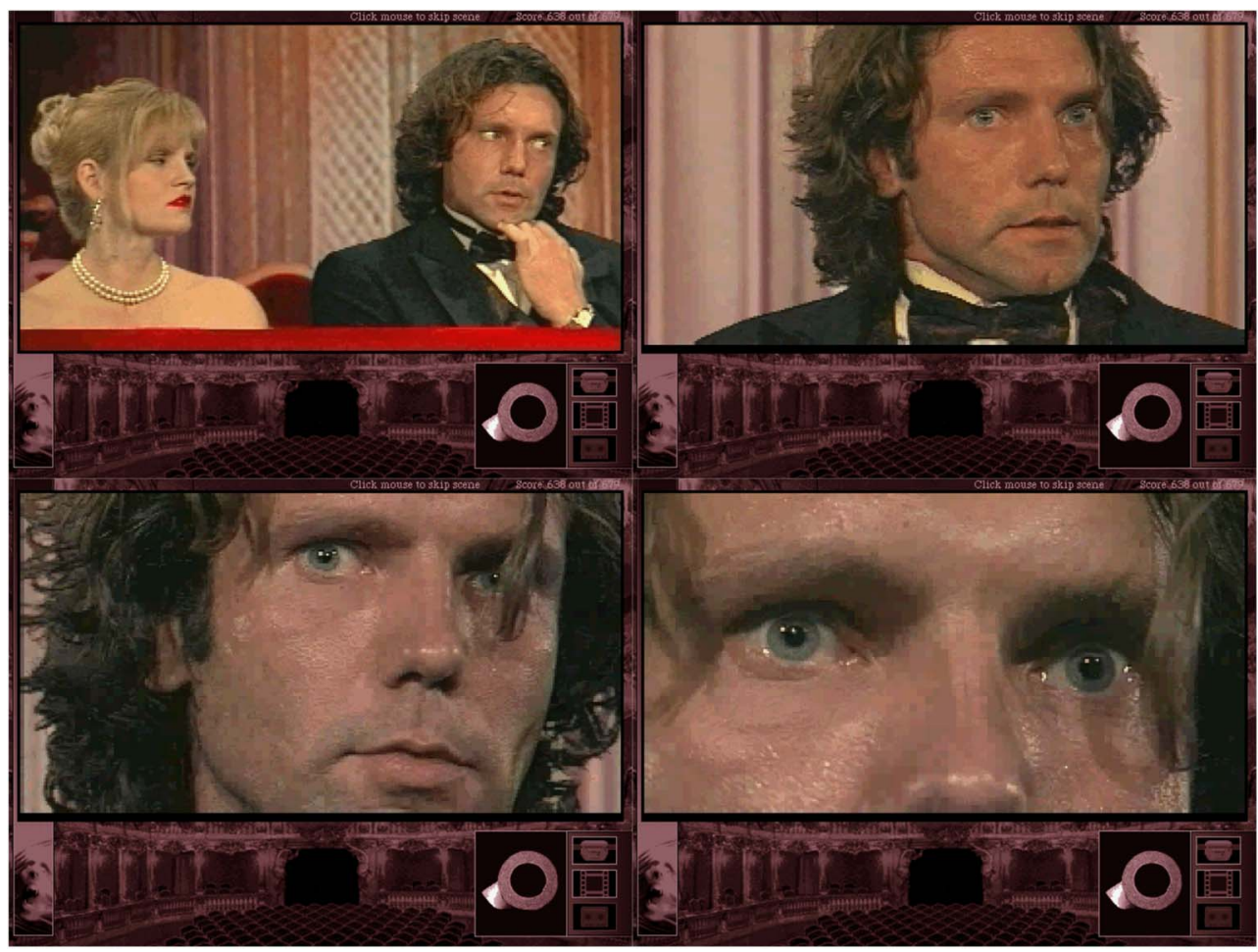

Fig. 7: Von Glower feels the effects of Wagner's music, prompting his transformation against his will in The Beast Within. Screen capture by Tim Summers, 15 August 2016.

Nietzsche's description of the physiological effect of Wagner's music is part of a strain of nineteenth- and twentieth-century criticism that alludes to, in Thomas Grey's words, 'Wagner's supposedly unhealthy impact on the nervous system'. ${ }^{89}$ More generally, Nietzsche's critical investigation into Wagner is centred on the term 'decadence/décadence', which has several spheres of significance. ${ }^{90}$ It maintains its commonplace meaning of decline and decay, but it is also used to criticise a supposedly modern mode of being, bound up with sickness (degeneracy), cultural degradation and, as Katherine Fry puts it, 'a modern creative aesthetic that stood opposed to classical values of beauty. ${ }^{91}$

89 Thomas S. Grey, 'Wagner the Degenerate: Fin de Siècle Cultural "Pathology" and the Anxiety of Modernism', Nineteenth Century Studies 16 (2002), 80.

90 Dieter Borchmeyer, 'Critique as Passion and Polemic: Nietzsche and Wagner', in The Cambridge Companion to Wagner, ed. Thomas S. Grey (Cambridge, 2008), 201. See also the same author's 'Wagner and Nietzsche', trans. Michael Tanner in Wagner Handbook, ed. Ulrich Müller, Peter Wapnewski and John Deathridge (Cambridge, MA, 1992), 327-42.

91 Katherine Fry, 'Nietzsche, Tristan und Isolde, and the Analysis of Wagnerian Rhythm', Opera Quarterly 29 (2013), 268. Wagner remains an inescapable figure in the discourse of musical decadence, but for a broader perspective involving other repertoires, see Steven Downes, Music and Decadence in European Modernism (Cambridge, 2010). 
Far beyond Nietzsche, Wagner's music has long been charged as somehow pathological 'as symptoms of an increasingly unhealthy modern cultural condition', most often through the term 'degenerate.'. ${ }^{2}$ Nancy Stepan notes, 'Degeneracy in this sense was a pervasive, subtle decay of the individual or group, a deviation from a standard of normality, which was caused by some transgression of social, moral, or physical rules and which became established within the hereditary constitution of the individual. ${ }^{93}$ As James Kennaway succinctly describes, the late nineteenth and early twentieth centuries

saw a steady stream of books and articles that argued that Wagner was sick, that his music was the expression of his own degeneration and indeed that the music could have pathological consequences for the audience. Indeed Wagner was by far the most important figure in the development of the idea of degenerate music. ${ }^{94}$

The nexus of personal/societal sickness and abnormal morality echoes our earlier discussion of Tosca/Hitman and The Beggar's Opera/Assassin's Creed; both games stage the operas alongside thrillingly transgressive behaviour. The Beast Within, in turn, depicts Wagner's music as physically, directly powerful and bound up with the occult. Like Parasite Eve, The Beast Within literally connects the operatic experience and sickness (in the former, the biological parasite, in the latter, werewolfery). For Nietzsche, Wagner's pathological degeneracy was no mere metaphor. Since the philosopher understood his own poor health as a 'nervous' condition, Wagner's psychological impact was directly related to his physical illness. ${ }^{95}$ The Beast Within dramatises such a relationship in terms of the werewolves. The regressive aspects of degeneracy were often described in terms of atavism and primitivism: as Thomas Grey describes, 'Wagner's critics would soon be diagnosing as a characteristically Wagnerian form of "degeneration" ... the activation of regressive, atavistic impulses ... without regard for the potentially destructive consequences. ${ }^{96}$ One such critic, Max Nordau, described degeneracy in terms particularly resonant with the image of the werewolf: as 'morbid deviation from an original type..

Charges of degeneracy and decadence were typically founded upon accusations of musical hysteria, unabashed and uncritical emotionalism, extravagance, spectacle and

92 Grey, 'Wagner the Degenerate', 79.

93 Nancy Stepan, 'Biological Degeneration: Races and Proper Places', in Degeneration: The Dark Side of Human Progress, ed. J. Edward Chamberlin and Sander L. Gilman (New York, 1985), 112.

94 James Kennaway, 'Musical Pathology in the Nineteenth Century: Richard Wagner and Degeneration', PhD diss. (University of California, Los Angeles, 2004), ix.

95 Sander L. Gilman, 'Nietzsche, Bizet, and Wagner: Illness, Health, and Race in the Nineteenth Century', The Opera Quarterly 23 (2007), 253. See also Clara Schumann's reports of her 'obvious distress .... at the affective content in the music' of Tristan; Laurence Dreyfus, Wagner and the Erotic Impulse (Cambridge, MA, 2010), 37-8.

96 Grey, 'Wagner the Degenerate', 74. For more on the racial and sexual aspect of degeneracy and decadence criticism, see Laurence Senelick, 'Offenbach, Wagner, Nietzsche: The Polemics of Opera', New Theatre Quarterly 32 (2016), 3-18; and Marc A. Weiner, 'Opera and the Discourse of Decadence: From Wagner to AIDS', in Perennial Decay: On the Aesthetics and Politics of Decadence, ed. Liz Constable, Denis Denisoff and Matthew Potolsky (Philadelphia, 1999), 119-41.

97 Max Nordau, Degeneration (London, 1913), 16. Nordau adopts this description from psychiatrist Bénédict Morel's 1857 treatise on degeneration. 
music that 'appeals ... to the sensory organs at a more direct, unmediated level'.98 Hysteria figured significantly in the discourse of degeneracy, ${ }^{99}$ revealing its association of femininity with superficiality, irrationality and, as Peter Franklin has suggested, popular culture. ${ }^{100}$ When Nordau's 'degeneracy' refers to aspects of creative work 'that might be deemed immoral, excessive, fantastic, illogical, or otherwise offensive to the canons of cultivated bourgeois taste and sensibilities', ${ }^{101}$ it is clearly reminiscent of the sensationalism characteristic of melodrama, as well as the supposed depravity of Tosca and The Beggar's Opera.

The Beast Within's depiction of Wagner's music demonstrates an affinity with the criticism of Wagner's music as powerfully, psychologically and physically decadent. Like the thrilling spectacle of the supposedly 'immoral' operas and action in Hitman and Assassin's Creed, the game celebrates the 'degenerate' and 'decadent' qualities of opera. By mirroring werewolves in the fictional opera with the werewolves in the game's plot, the game argues that Wagner's opera holds similar topics and expressive values to the game as a whole. The questionable resemblance of Engelhart to Wagner's actual output aside, Wagner's opera is here depicted as harbouring physical power, spectacular and sensationalist effects, and using direct expression: it is presented melodramatically, adopting those very same aesthetic values I have argued resonate with those of video games.

The game makes the opposite argument to Nietzsche - that the music is powerful in the same terms, but here is deployed in the service of cure, rather than perpetuating sickness. While transfiguration (Verklärung) in Wagner's music dramas is properly understood in far more metaphysical and transcendent terms that that represented here, the process of transformation nevertheless thematically resonates with this scene where two people undergo a form of transfiguration at Wagner's command - one on his way to redemption, the other to condemnation. $^{102}$

Katherine Fry has argued that Nietzsche's accusation of decadence and degeneracy is grounded in Wagner's treatment of rhythm: Nietzsche 'regards the effect of rhythmic ambiguity as a symptom of decay that threatens the health of modern music', since the 'rhythmic content is dynamic, multifarious, and irrational'. ${ }^{103}$ Fry illustrates the significance of Wagner's rhythm to Nietzsche's experience of the music. Two aspects are particularly telling: first, the degree to which rhythm is related to the construction of the fictional world in Wagner's opera, and second, that Nietzsche's

\footnotetext{
98 Grey, 'Wagner the Degenerate', 80.

99 Grey, 'Wagner the Degenerate', 82.

100 Peter Franklin, Reclaiming Romantic Music (Berkeley, 2014), 31.

101 Grey, 'Wagner the Degenerate', 77.

102 On Wagnerian transfiguration, see Karol Berger, 'A Note on Tristan's Death Wish', in Richard Wagner and His World, ed. Thomas S. Grey (Princeton, 2009), 123-32; and R.J.A. Kilbourn, 'Redemption Revalued in Tristan und Isolde: Schopenhauer, Wagner, Nietzsche', University of Toronto Quarterly 67 (1998), 781-8.

103 Fry, 'Nietzsche, Tristan und Isolde', 268, 271. See also Aaron Ridley, 'Nietzsche, Wagner, Decadence', Opera Quarterly 29 (2013), 277-81.
} 
experience of Wagnerian musical fabric is somehow 'overwhelming' and perceptionaltering. ${ }^{104}$ The connection between operatic expression and the construction of a virtual world will form the final part of this exploration.

Nietzsche, of course, was far from the only critic to characterise Wagner as a seductive manipulator. Many commentators have grappled with the same kind of intoxicating, perception-altering sensory experience of Wagnerian music drama that he describes. ${ }^{105}$ Chief among Nietzsche's heirs in this respect was Theodor Adorno, who describes the overwhelming aesthetic effects of Wagner in terms of 'phantasmagoria'. Drawing on Marx by way of Walter Benjamin, ${ }^{106}$ he describes phantasmagoria as 'the perfection of the illusion that the work of art is a reality sui generis ... [a] magic delusion'. ${ }^{107} \mathrm{He}$ borrows Paul Bekker's words to call it "The "illusion of the absolute reality of the unreal.",108 Adorno has in mind a kind of aesthetic excess that overcomes critical distance and creates a distinct compelling reality which seduces listeners into engaging with the artificial worlds. Adorno ultimately regards the phantasmagoria as an 'insidious deception' (in Alistair Williams's characterisation). ${ }^{109}$ As Marc A. Weiner describes, it is

a numbing, sensual bombardment of the listening viewer, resulting purportedly in a drug-like seduction ... lull[ing] the audience into perceiving the artificial construct as a natural phenomenon, into emotionally and imaginatively participating in or identifying with the aesthetically induced fantasy. ${ }^{110}$

Adorno is particularly concerned with technologies that 'conceal the labour that has gone into making' the phantasmagoria. ${ }^{111}$ As Sherry Lee has pointed out:

The phantasmagorical concept can also be seen in Wagner's efforts to create the illusion of a magical onstage world through technology-the elaborate behind-thescenes machinery, and especially the orchestral effects, engineered so that the physical means of producing individual instrumental sounds are obscured. ${ }^{112}$

104 Fry, 'Nietzsche, Tristan und Isolde', 271.

105 Kennaway, 'Musical Pathology', 170ff.

106 For comparisons between Adorno's treatment of phantasmagoria with that of Marx and Benjamin, see Adrian Daub, 'Adorno's Schreker: Charting the Self-Dissolution of the Distant Sound', Cambridge Opera Journal 18 (2006), 247-71; Stephen Decatur Smith, 'Awakening Dead Time: Adorno on Husserl, Benjamin, and the Temporality of Music', Contemporary Music Review 31 (2012), 389-409 and Alastair Williams, 'Technology of the Archaic: Wish Images and Phantasmagoria in Wagner', Cambridge Opera Journal 9 (1997), 73-87. Adorno would subsequently deploy this concept in his criticism of Franz Schreker.

107 Theodor Adorno, In Search of Wagner, trans. Rodney Livingstone (London, 2005), 74.

108 Paul Bekker, Wagner, Das Leben im Werke (1924), quoted in Adorno, Wagner, 79.

109 Alistair Williams, 'Répons: Phantasmagoria or the Articulation of Space?', in Theory, Analysis, and Meaning in Music, ed. Anthony Pople (Cambridge, 1994), 206.

110 Weiner, 'Why Does Hollywood Like Opera?', 78.

111 Adorno, Wagner, 80. As Adrian Daub describes, the "façade of the "technology" hides the ... produced-ness of the phantasmagoria'. 'Adorno's Schreker', 250.

112 Sherry Lee, 'A Minstrel in a World without Minstrels: Adorno and the Case of Schreker', Journal of the American Musicological Society 58 (2005), 650. 
Adorno famously identifies the Gesamtkunstwerk as a tool for phantasmagoric creation. In Max Paddison's explication:

$[T]$ he 'blending' of essentially different modes of art into a new synthesis ... has as its intention the concealing of the joins, and of the artifice of the process of artistic production itself. The contradiction here is that the concealment of artifice through the illusion of 'nature' results in the art work as separate, distinct and alienated from nature. ${ }^{113}$

There are clear resonances between the 'illusion of the absolute reality of the unreal' and the way that games aim to create compelling, fantastic but believable fictional realities in the form of their virtual worlds. ${ }^{114}$ Wagnerian phantasmagoria has been seen to prefigure cinema. ${ }^{115}$ We might admit video games, as ostentatiously modern and technologically ambitious, into this media lineage. If 'the Bayreuth experience ... aimed to engross the spectator entirely', ${ }^{116}$ games aim to do the same - not for nothing has the term 'immersion' become a focal point of much game criticism. ${ }^{117}$

As an interactive medium, the player's active engagement with the worlds and characters is at the heart of the success or failure of the game. If I do not care about the plot or ludic challenge, if I do not find motivation to control my avatar, if I do not receive emotional reward from the game or become engaged with the virtual world, I will simply stop playing. In addition, games continually have to contend with foregrounded artificiality: the mechanics of control (such as the ever-visible control panel in Figs. 5-7), the not-quite-realistic images, and the clunky logic of gameplay. Games are concerned with the ostentatious deployment of technology to create seductively engaging fictional worlds. In comparison with film, phantasmagoria is at once even more desirable, and even more demanding, for games. ${ }^{118}$

Kennaway argues that phantasmagoria sits within a nexus of associated properties that include features of mass culture, feminine hysterical irrationality and sensationalism: 'stimulat[ing] the tired nerves of modern audiences and seduc[ing] the senses rather than engaging the rational self'. 119 The charge of sensationalist irrationality echoes the qualities of melodramatic aesthetics discussed earlier. In addition, the medicinal dimension of descriptions that talk of hypnosis and drugs recalls the

113 Max Paddison, Adorno's Aesthetics of Music (Cambridge, 1993), 245. Paddison continues by noting the paradox of Adorno's argument, 'On the one hand, Wagner's "perfection of illusion" as phantasmagoria derives from the fantastic aspects of Romanticism, the attempt to transcend everyday reality through the creation of a magical alternative reality. On the other hand, however, Adorno suggests that it also signals the birth of realism.'

114 On the tension between realism and fantasy in game audio, see Richard Stevens and Dave Raybould, 'The Reality Paradox: Authenticity, Fidelity and the Real in Battlefield 4', The Soundtrack 8 (2015), 57-75.

115 Kennaway, 'Musical Pathology', 167, 179.

116 Kennaway, 'Musical Pathology', 191.

117 For a concise introduction see Carl Therrien, 'Immersion', in The Routledge Companion to Video Game Studies, ed. Wolf and Perron, 451-8.

118 Another point-and-click game from the same company as The Beast Within, released the same year, is tellingly titled Phantasmagoria (1995).

119 Kennaway, 'Musical Pathology', 167. 
supposedly poisoning effects of the operas of Puccini and Gay, as well as violent games. Kennaway himself alludes to this connection:

In psychiatric and journalistic literature the technological and musical effects of Bayreuth were understood as expressions of ultramodern, hypnotic, hysterical, degenerate Rausch. The Gesamtkunstwerk was a foretaste of modern mass media technology, and its reception as degenerate prefigured much of the ambiguity which that technology has been provoked since. ${ }^{120}$

Scenes of staged opera in games serve the phantasmagoric aspirations of games in a similar way. In these ostentatious moments of operatic audio-visual spectacle, the discrete components that constitute the technology of the game (the programming architecture, audio files, visual materials, user interface, and so on) unite to produce a performed whole. It is a moment at which the Gesamtkunstwerk of the game coalesces. By engaging sonic and visual aspects of the medium in a unified way, in a moment of coherent operatic expression, we do not see the atomised construction, but the illusion of a holistic reality in which we witness the performance. In operas in games, we witness virtual singers, conjured from and dissolved into nothing. They are apparently present to our senses, but distinctly projected in another space, often with odd-sounding and out-of-sync voices. Nevertheless, through the operatic activity, they performatively assert their expressive potential, irrespective of their intangibility.

Games seek to overcome the same critical distance that Adorno was worried that Wagnerian aesthetics dissolve, to create compelling virtual worlds with the aim of engrossing the player. It is not so surprising that operatic scenes which use a melodramatic aesthetic of excess should be apt for such a project. The opera scenes in The Beast Within occur after (at least) nine hours of playing the game, just before the final challenge, representing the perfect cumulative point at which to make the final bid for aesthetic substantiality of the game experience.

For all that Wagner's work is so often a target for ridicule in popular culture, it is not parodied in The Beast Within. We see no Nazi icons, nor horned helmets. It argues for Wagner's operatic output as historicised but with direct appeal. Simultaneously, however, this music is at the core of the pulp-fiction werewolf plot and the horror mystery. No high-minded abstraction, Wagner's opera is depicted as bound up with easily comprehended comedy, visceral sensation and corporeality.

Opera is here used to create a musical moment for gamers, at once de-rarefying opera in terms of its socially elite status, yet retaining claims for its transformative power and importance through direct experience. We are encouraged to marvel at the musical power of Wagner. When the game portrays his opera as potent enough to change the physicality of characters, it thematises the role of staged opera in games, where the musical-visual expressive spectacle, as integrated performance, serves to bolster the phantasmagoria of the game's reality. ${ }^{121}$

120 Kennaway, 'Musical Pathology', 172.

121 On the significance of shared musical experience with fictional characters, see Ben Winters, Music, Performance, and the Realities of Film (New York, 2014), 186-98. 


\section{Opera and compelling worlds of play}

My investigation here has attempted to illuminate some of the meanings and aesthetic effects generated by scenes of staged opera in games. It has also been concerned with the discourse about opera that these games enact through their representations, and the parallels with studies of opera in film. The video game is, however, a distinctly different medium to film. In video games, player and game are bound together in active interactivity, and player engagement is of paramount importance. ${ }^{122}$ Video games, unlike film, cannot afford to deploy 'operatics of detachment', as Citron described in Quantum of Solace. Anything that might risk player disengagement is to be avoided - it is for this reason that the opera scenes are so sincerely and earnestly deployed; no moment of rupture or tension, they encourage engagement in a way that accentuates the common ground of the two media.

By engaging with long-standing tropes of associating opera with disease, alterity, and personal and social degradation (especially in the biological sickness in Parasite Eve and The Beast Within, the criminality of Assassin's Creed and the violence in Hitman), these games invite us not to stand at a distance and condemn the degenerate decadence, but rather become complicit as we identify with the characters, control the avatars engaging in violence, and revel in the ostentatiousess in the opera scenes. We enjoy and share in the opera; any agenda founded upon critical detachment would be anathema to the game medium's priority of player involvement. Operatic expression - particularly in Parasite Eve, Final Fantasy VI and The Beast Within - is shown as honest, direct, accessible and emotionally affecting. As such, games and opera illustrate the potential for the simultaneity of both melodramatic sensationalism and sincere aesthetic significance. This is hardly a revelation to most opera-goers, but it is an aspect of opera generally neglected in popular depictions that support either an agenda of elite cultural prestige for the medium, or critically position it as the music of degenerate decadence.

The video game has often been characterised as a lowbrow medium. While widespread recognition of its artistic merit is increasing, the change is slow. When games stage opera in their virtual worlds, and present not an idealised, sanitised and abstracted vision of opera, but one with spectacular sensationalism, and extremes of emotion and action, they lay claim to an aesthetic similarity between games and opera. For games, there is much to be gained in terms of cultural prestige through adopting the operatic register. When opera and games fuse, the similarities between seemingly disparate art forms are accentuated, and the shared pleasures, values and experiences made obvious. These operatic moments make the case for an artistic reception of games, as well as a popular reception of opera. Opera formulates important game moments that are compelling and rewarding for gamers. For players unfamiliar with opera, these games advance an image of the medium different to many pop-culture depictions of opera.

122 Collins, Playing With Sound, 2-15; Torben Grodal, 'Video Games and the Pleasures of Control', in Media Entertainment: The Psychology of Its Appeal, ed. Dolf Zillman and Peter Vorderer (Mahwah, NJ, 2000), 201. 
Games rely on the creation of virtual universes as spaces for play to a greater extent than films. As media theorist Torben Grodal notes, gamers must normally 'make mental maps of the gamespace. ${ }^{123}$ Players' understanding of the consistent virtual world, and how it reacts to their actions, underpins the interactive connection of game and player. ${ }^{124}$ When the game realities are important, and technical factors that foreground their constructedness ever-present, the creation of the phantasmagoric world is both more important, and more challenging than in film.

Players therefore experience opera scenes staged in games as aesthetically stimulating, technologically impressive and absorbing moments. Just as in Wagnerian opera before them, these often thrilling sequences use affecting audio-visual spectacle to compel gamers to engage with the virtual conceit. At these points, which unite, on the one hand, disparate technological elements of the game construct, and on the other, enacted musical expression, the virtual reality is projected as an integrated whole. By staging an opera in the game world, those game universes (and the characters who live in them) are strikingly formed.

The operatic worlds in games may not have the best voices, the widest repertoire, or the most innovative staging. They may be pixelated and abbreviated. Nevertheless, for the huge audiences the games reach, they provide novel and interesting modes of operatic engagement and interaction. They speak to - and promote the enjoyment and significance of - opera to a demographic that may not otherwise engage with the medium. Further, they do so in a player-empowered, inclusionary fashion. Staged opera in games has created aesthetically rewarding, captivating and emotionally substantial moments; moments that can provide new operatic experiences with which to play.

TIM SUMMERS is Lecturer in Music at University College Dublin. He researches music in popular culture, often focusing on video games. He is the author of Understanding Video Game Music (Cambridge University Press, 2016) and, on the same topic, he has edited an issue of The Soundtrack and a collection of essays, Ludomusicology: Approaches to Video Game Music (Equinox, 2016). He has written for journals including The Journal of the Royal Musical Association, The Journal of Film Music and Music, Sound, and the Moving Image. $\mathrm{He}$ is currently writing a second monograph and editing the Cambridge Companion to Video Game Music.

123 Grodal, 'Pleasures of Control', 202, 207.

124 Mark J.P. Wolf, 'Worlds', in The Routledge Companion to Video Game Studies, ed. Wolf and Perron, 125-6. 